\title{
Seasonal and Spatial Distribution of Freshwater Flow and Salinity in the Ten Thousand Islands Estuary, Florida, 2007-2009
}

By Lars E. Soderqvist and Eduardo Patino

Prepared in cooperation with the South Florida Water Management District

Data Series 501 


\title{
U.S. Department of the Interior \\ KEN SALAZAR, Secretary \\ U.S. Geological Survey \\ Marcia K. McNutt, Director
}

\section{U.S. Geological Survey, Reston, Virginia: 2010}

\author{
For more information on the USGS — the Federal source for science about the Earth, its natural and living resources, \\ natural hazards, and the environment, visit http://www.usgs.gov or call 1-888-ASK-USGS \\ For an overview of USGS information products, including maps, imagery, and publications, \\ visit http://www.usgs.gov/pubprod \\ To order this and other USGS information products, visit http://store.usgs.gov
}

\begin{abstract}
Any use of trade, product, or firm names is for descriptive purposes only and does not imply endorsement by the U.S. Government.

Although this report is in the public domain, permission must be secured from the individual copyright owners to reproduce any copyrighted materials contained within this report.
\end{abstract}

Suggested citation:

Soderqvist, L.E., and Patino, Eduardo, 2010, Seasonal and Spatial Distribution of Freshwater Flow and Salinity in the Ten Thousand Islands Estuary, Florida, 2007-2009: U.S. Geological Survey Data Series 50124 p.. 


\section{Contents}

Abstract
Introduction
$\quad$ Purpose and Scope
Description of Study Area
Seasonal and Spatial Distribution of Freshwater Flow and Salinity
Limitations of the Salinity Maps
Acknowledgments
References Cited

\section{Figures}

1. Map showing study area, including Picayune Strand Restoration Project, Fakahatchee Strand, canals, major tidal bays, Gulf of Mexico, locations of U.S. Geological Survey and Rookery Bay National Estuarine Research Reserve monitoring stations, and non-monitored rivers within the study area...............................2

2. Photograph of flow-through chamber that uses forward boat movement to force surface water past a water-quality probe during salinity surveys

3. Photograph of instrument setup used during salinity survey, including data logger, flow-through chamber, and Global Positioning System unit..............................................

4. Map showing boat tracks followed during salinity survey. Two boats operate simultaneously on inside and outside tracks to provide greater coverage...

5. Time-series charts showing raw salinity data for a single survey performed May 14, 2008, with erroneous readings prior to editing, and salinity data after editing

6-18. Maps showing-

6. Point data collected during the September 6, 2007 salinity survey...

7. Barriers used to prevent interpolation between adjacent but independent water bodies during generation of raster layers using inverse distance weighted function.

8. Salinity patterns in the Ten Thousand Islands during end of dry season on May 10, $2007 .$.

9. Salinity patterns in the Ten Thousand Islands during transition to wet season on June 29, 2007

10. Salinity patterns in the Ten Thousand Islands during middle of wet season on September 6, 2007

11. Salinity patterns in the Ten Thousand Islands during middle of wet season on October 23, 2007

12. Salinity patterns in the Ten Thousand Islands during transition to dry season on December 20, 2007 
13. Salinity patterns in the Ten Thousand Islands during end of dry season on May 14, 2008.

14. Salinity patterns in the Ten Thousand Islands during transition to wet season on July 11, 2008

15. Salinity patterns in the Ten Thousand Islands during middle of wet season on September 25, 2008

16. Salinity patterns in the Ten Thousand Islands during transition to dry season on January 8, 2009

17. Salinity patterns in the Ten Thousand Islands during end of dry season on May 7, 2009

18. Salinity patterns in and around Fakahatchee Bay on May 14, 2008

19. Bar graph showing comparison of rainfall in the Ten Thousand Islands watershed during 2007 and 2008, as measured by the South Florida Water Management District. Data are a mean of FKSTRN, DANHP, SGGEWX, and COLLISEM stations obtained from the South Florida Water Management District DBHYDRO database ......21

20. Time-series chart showing surface salinities at four U.S. Geological Survey monitoring stations on and around the July 11, 2008 salinity survey

21. Time-series chart showing surface and bottom salinities at the Blackwater River monitoring station on and around the July 11, 2008 salinity survey.

\section{Tables}

1. Wet and dry season discharge at USGS monitoring stations in the Ten Thousand Islands, January-December 2008 


\section{Conversion Factors, Acronyms, and Datum}

\begin{tabular}{rcl}
\hline \multicolumn{1}{c}{ Multiply } & \multicolumn{1}{c}{ To obtain } \\
\hline & Length & \\
inch (in.) & 2.54 & centimeter $(\mathrm{cm})$ \\
inch (in.) & 25.4 & millimeter $(\mathrm{mm})$ \\
foot $(\mathrm{ft})$ & 0.3048 & meter $(\mathrm{m})$ \\
mile (mi) & 1.609 & kilometer $(\mathrm{km})$ \\
& Area & \\
& 2.590 & square kilometer $\left(\mathrm{km}^{2}\right)$ \\
square mile $\left(\mathrm{mi}^{2}\right)$ & Velocity & \\
& & \\
mile per hour $(\mathrm{mi} / \mathrm{h})$ & 1.609 & kilometer per hour $(\mathrm{km} / \mathrm{h})$ \\
& Flow Rate & \\
& 0.02832 & cubic meter per second $\left(\mathrm{m}^{3} / \mathrm{s}\right)$ \\
\hline
\end{tabular}

Temperature in degrees Celsius $\left({ }^{\circ} \mathrm{C}\right)$ may be converted to degrees Fahrenheit $\left({ }^{\circ} \mathrm{F}\right)$ as follows:

${ }^{\circ} \mathrm{F}=\left(1.8 x^{\circ} \mathrm{C}\right)+32$

\begin{tabular}{l|l}
\hline CERP & Comprehensive Everglades Restoration Plan \\
ESRI & Environmental Systems Research Institute \\
FCS & Faka Union Canal System \\
GIS & Geographic Information System \\
GPS & Global Positioning System \\
IDW & Inverse distance weighted \\
ppt & parts per thousand \\
PSRP & Picayune Strand Restoration Project \\
RBNERR & Rookery Bay National Estuarine Research Reserve \\
SFWMD & South Florida Water Management District \\
SGGE & Southern Golden Gate Estates \\
TTCP & Tamiami Trail Culverts Project \\
TTI & Ten Thousand Islands \\
USGS & U.S. Geological Survey
\end{tabular}

Horizontal coordinate information is referenced to the North American Datum of 1983 (NAD 83). 



\title{
Seasonal and Spatial Distribution of Freshwater Flow and Salinity in the Ten Thousand Islands Estuary, Florida, 2007-2009
}

\author{
By Lars E. Soderqvist and Eduardo Patino
}

\section{Abstract}

The watershed of the Ten Thousand Islands (TTI) estuary has been substantially altered through the construction of canals and roads for the Southern Golden Gate Estates (SGGE), Barron River Canal, and U.S. 41 (Tamiami Trail). Two restoration projects designed to improve freshwater delivery to the estuary are the Picayune Strand Restoration Project, which includes the Southern Golden Gate Estates, and the Tamiami Trail Culverts Project; both are part of the Comprehensive Everglades Restoration Plan. To address hydrologic information needs critical for monitoring the effects of these restoration projects, the U.S. Geological Survey initiated a study in October 2006 to characterize freshwater outflows from the rivers, internal circulation and mixing within the estuary, and surface-water exchange between the estuary and Gulf of Mexico. The effort is conducted in cooperation with the South Florida Water Management District and complemented by monitoring performed by the Rookery Bay National Estuarine Research Reserve.

Surface salinity was measured during moving boat surveys using a flow-through system that operated at planing speeds averaging 20 miles per hour. The data were logged every 10 seconds by a data recorder that simultaneously logged location information from a Global Positioning System. The major rivers, bays, and nearshore Gulf of Mexico region of the TTI area were surveyed in approximately 5 hours by two boats traversing about 200 total miles. Salinity and coordinate data were processed using inverse distance weighted interpolation to create salinity contour maps of the entire TTI region.

Ten maps were created from salinity surveys performed between May 2007 and May 2009 and illustrate the dry season, transitional, and wet season salinity patterns of the estuarine rivers, inner bays, mangrove islands, and Gulf of Mexico boundary. The effects of anthropogenic activities are indicated by exceptionally low salinities associated with point discharge into the estuary from the Faka Union Canal and Barron River during the wet season. Low salinities in Faka Union Bay may cause reduced diversity and density of submerged aquatic vegetation, fish, and benthic organisms compared with neighboring Fakahatchee Bay. The Faka Union Canal System reduced the size of the watershed for the western TTI estuary, resulting in increased wet season salinities compared to those for the eastern TTI estuary, the watershed of which is composed of the relatively pristine Fakahatchee Strand Preserve State Park. Minimal river discharge and high evaporation caused hypersaline conditions to develop throughout the entire TTI region during the dry season. The 2007-2008 drought and passage of Tropical Storm Fay on August 18-19, 2008, demonstrated the effects of seasonal rainfall on salinity patterns, with substantially higher salinities observed during the 2007 wet season compared to those for the 2008 wet season. The salinity maps, coupled with data from the monitoring stations, provide baseline information of seasonal and spatial distribution of freshwater flow and salinity in the TTI estuary, and a means of monitoring the effects of restoration in improving freshwater delivery to the estuary.

\section{Introduction}

The ability of an estuary to function properly depends on the quality, quantity, timing, and distribution of freshwater flowing to the estuary (Summers, 1999). Human-induced changes to the watershed of an estuary can alter salinity patterns and water quality, negatively affecting productivity, structure, and behavior of estuarine plant and animal communities (Sklar and Browder, 1998).

The watershed of the Ten Thousand Islands (TTI) estuary has been substantially altered by construction associated with the Southern Golden Gate Estates (SGGE) project, U.S. 41 and Tamiami Canal, and Barron River Canal (fig. 1). The SGGE is an $86 \mathrm{mi}^{2}$ failed housing project located in the western half of the TTI watershed. Forty-eight mi of canals, collectively known as the Faka Union Canal System (FCS), were constructed in an attempt to drain the project area. Prior to construction of the FCS, slow overland sheetflow kept the wetlands in this region hydrated well into the dry season. Freshwater flowed from the watershed into the estuary over 


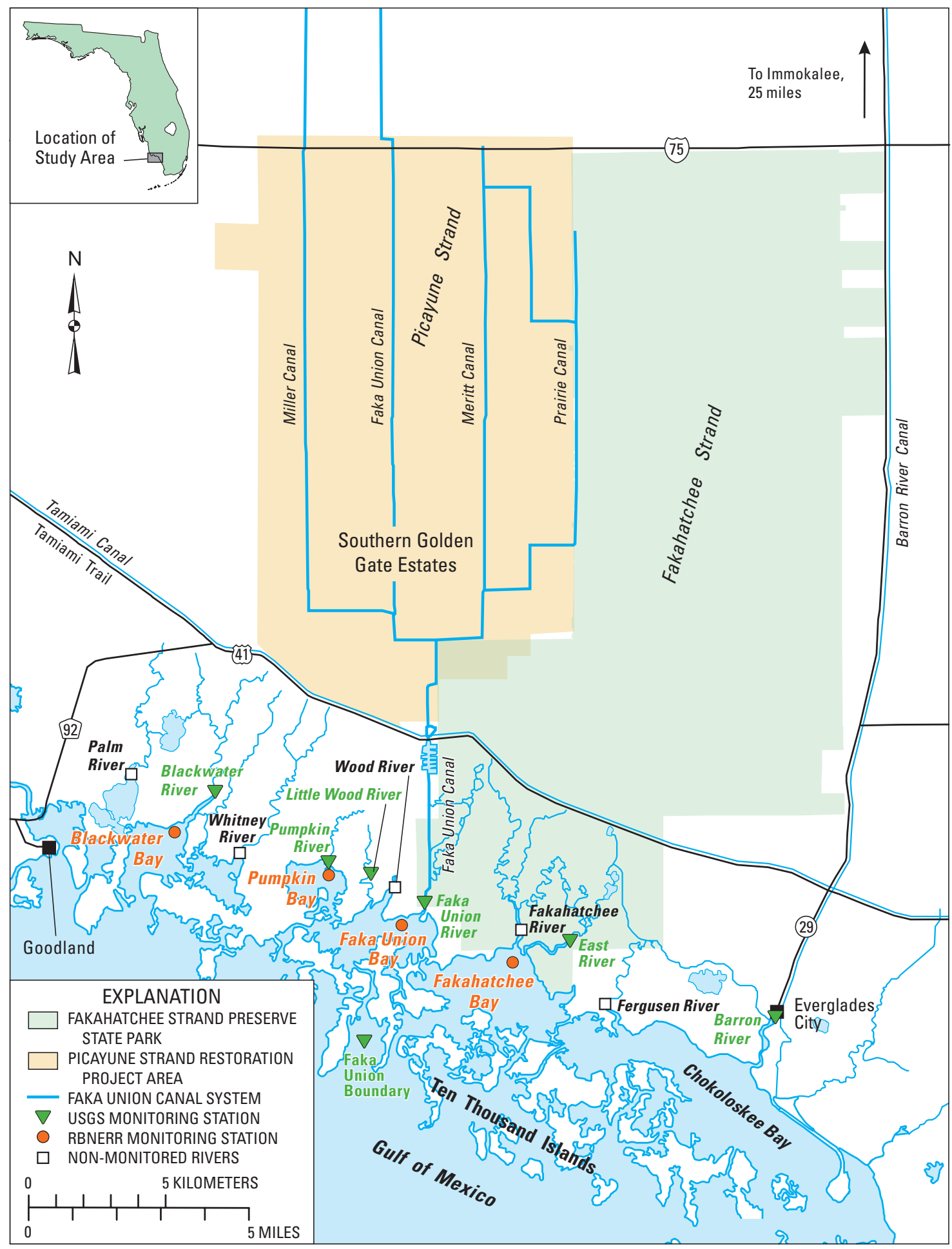

Base from U.S. Geological Survey digital data,

Universal Transverse Mercator Zone 17

Figure 1. Study area, including Picayune Strand Restoration Project, Fakahatchee Strand, canals, major tidal bays, Gulf of Mexico, locations of U.S. Geological Survey and Rookery Bay National Estuarine Research Reserve monitoring stations, and non-monitored rivers within the study area. 
a wider area, and occurred over a longer period of time, than after canal construction. Construction of the FCS accelerated drainage within the watershed, reducing wetland coverage, aquifer recharge, and base flow into the estuaries (South Florida Water Management District Big Cypress Basin and U.S. Department of Agriculture Natural Resources Conservation Services, 2003). In the altered system, freshwater discharges through the Faka Union Canal into the TTI estuary in large pulses at a single point, Faka Union Bay (fig. 1) (U.S. Army Corps of Engineers, 2008).

As with the Faka Union Canal System, Tamiami Canal and Barron River Canal funnel water into selected areas and decrease flow to surrounding areas, disrupting the predevelopment hydrology of the downstream wetlands and estuary (U.S. Army Corps of Engineers, 1998). Sheetflow in the TTI watershed north of Tamiami Trail is intercepted by the Tamiami Canal (a borrow canal along the north side of the Tamiami Trail, fig. 1) and conveyed further south through only a few bridges and culverts. Barron River Canal has artificially increased the size of the Barron River watershed, and simultaneously reduced the time required for freshwater to travel from the upstream wetlands to the estuary.

Two Comprehensive Everglades Restoration Plan (CERP) projects were initiated to improve freshwater delivery to the TTI estuary: the Picayune Strand Restoration Project (PSRP, formerly SGGE Restoration Project) and the Tamiami Trail Culverts Project (TTCP). The goal of the PSRP is to "restore historic hydroperiods and sheetflow patterns in the study area to the extent possible, while maintaining the existing levels of flood protection for areas north of the SGGE" (U.S. Army Corps of Engineers, 2004). This restoration plan involves removing existing roads, plugging existing canals, and constructing spreader channels and pump stations to restore sheetflow through the region while maintaining flood control capacity for communities to the north. The PSRP is closely related to the TTCP, which involves the construction of 14 additional culverts under the Tamiami Trail within the TTI watershed. These culverts will provide a path for the restored sheetflow exiting Picayune Strand to continue southward toward the estuary (U.S. Army Corps of Engineers, 1998). As of this writing, the TTCP had been completed and the PSRP had been initiated.

Hydrologic information regarding the TTI estuary is necessary to accurately monitor the results of the PSRP and TTCP restoration projects. In October 2006, the U.S. Geological Survey (USGS) initiated a study, in cooperation with the South Florida Water Management District (SFWMD), to characterize freshwater outflows from the rivers, internal circulation and mixing within the estuary, and surface-water exchange between the estuary and the Gulf of Mexico. The initial effort involved hydrologic monitoring at six estuarine rivers and one offshore location in the TTI estuary, and was complemented by monitoring performed by the Rookery Bay National Estuarine Research Reserve (RBNERR) in four bays downstream of the USGS estuarine river stations (fig. 1). Because data regarding seasonal salinity patterns within unmonitored bays and rivers were still lacking, the initial effort was expanded to include periodic salinity surveys of the region, which began in May 2007 and are planned to continue through May 2010. These surveys augment the monitoring network by providing "snapshot" salinity maps of the entire TTI estuary.

The data presented herein provide baseline information prior to the completion of the PSRP, as well as a means of monitoring the changes in freshwater delivery to the estuary resulting from restoration activities. These data may also be useful for calibration and post-audit of local hydrologic models, such as the TTI-area model (Swain and Decker, 2009) and the three-dimensional model of Port of the Islands (Decker and others, 2008).

\section{Purpose and Scope}

The purpose of this report is to characterize the seasonal and spatial distribution of freshwater flow and salinity in the TTI area during 2007-2009, primarily through the interpretation of salinity maps. The techniques used to collect data during salinity surveys of the TTI estuary are documented. Methods for data analysis, processing, and production of salinity maps are discussed, as well as limitations of the salinity maps. Data collected during the salinity surveys include location coordinates, time, salinity, and temperature. All salinity maps produced up to the time of report publication are also presented, including data collected between May 10, 2007, and May 7, 2009.

\section{Description of Study Area}

The study area encompasses tidal rivers, inner bays, mangrove island region, and nearshore open waters that compose the TTI estuary. The study area is bounded to the west by County Road 92, to the east by S.R. 29, to the north by U.S. 41, and to the south by the Gulf of Mexico (fig. 1). The TTI area is a shallow, subtropical estuarine system that consists of numerous bays separated from the Gulf of Mexico by many small islands and tidal passes. The area receives semidiurnal mixed tides with a range of approximately $3 \mathrm{ft}$. Ten major river systems are present in the study area, consisting (from east to west) of Barron River, Ferguson River, East River, Fakahatchee River, Faka Union Canal, Wood River, Little Wood River, Pumpkin River, Whitney River, and Palm River.

As previously noted, the Barron River and Tamiami Canals parallel S.R. 29 and U.S. 41, respectively, and the Faka Union Canal System is located in the former SGGE project area. The FCS is composed of the Miller Canal, Faka Union Canal, Meritt Canal, and Prairie Canal.

Although not directly affected by the PSRP and TTCP restoration projects, Barron River and Chokoloskee Bay were included in the study area due to (1) their proximity to the PSRP and TTCP restoration projects, and (2) the perceived importance of discharge from Barron River Canal, 


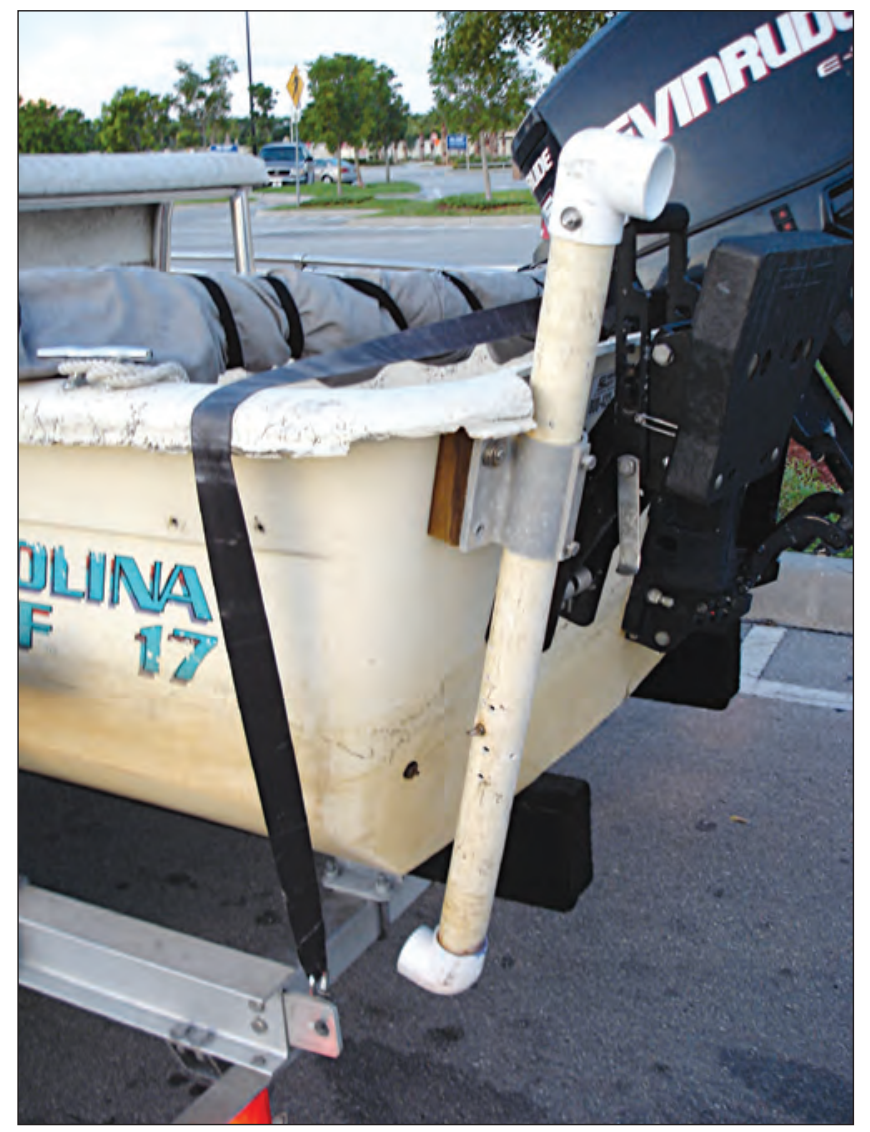

Figure 2. Flow-through chamber that uses forward boat movement to force surface water past a water quality probe during salinity surveys.

which drains a watershed of approximately $296 \mathrm{mi}^{2}$ (fig. 1). Freshwater is discharged from the Barron River Canal into Barron River at the northern end of Everglades City, entering the TTI estuary at Chokoloskee Bay (South Florida Water Management District, 2006).

\section{Data Collection and Production of Salinity Maps}

Salinity surveys used to create the maps were performed at least four times per year, covering conditions typical of the rivers and bays within the study area, including the height of the dry season (April - May), transition from dry to wet season (June - August), height of the wet season (September - October), and transition from wet to dry season (December - January).

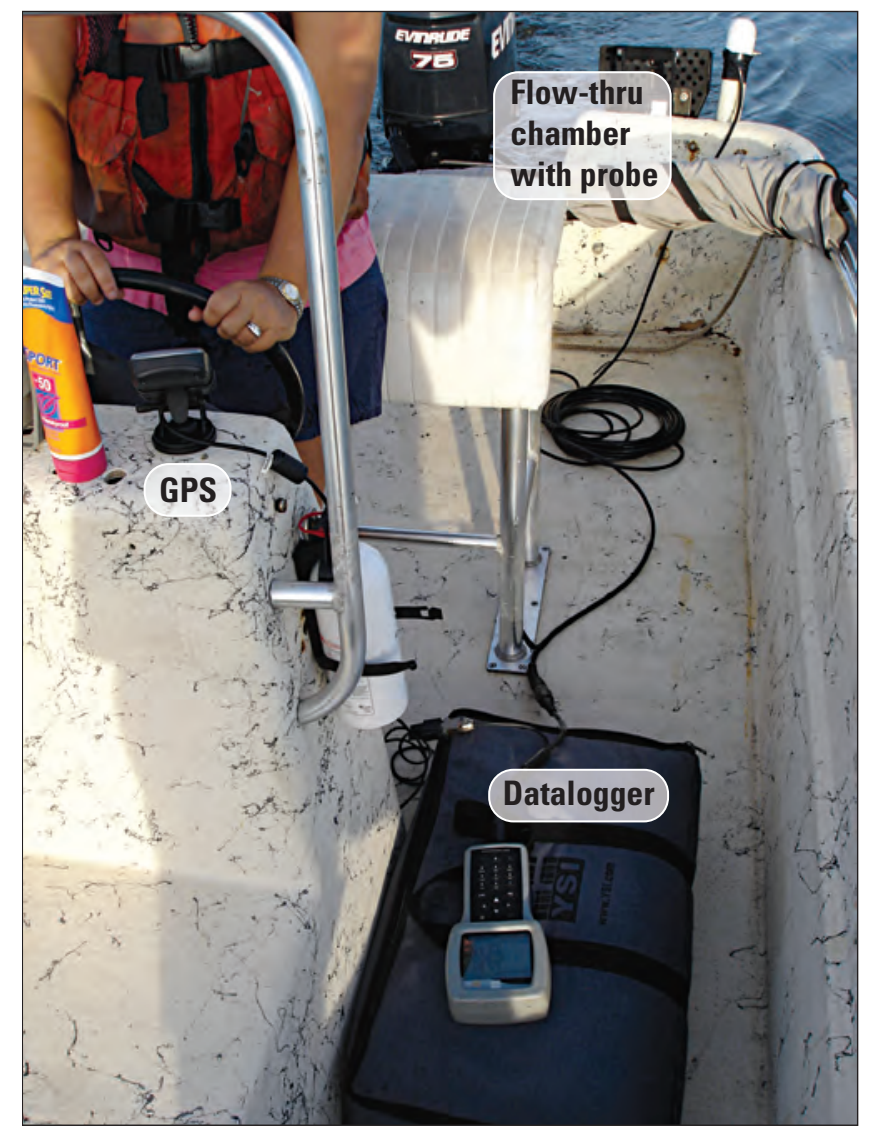

Figure 3. Instrument setup used during salinity survey, including the data logger, flow-through chamber, and Global Positioning System (GPS) unit.

Data collected during the surveys included location coordinates, time, salinity and temperature. The salinity maps were produced once the field data were analyzed and edited.

Procedures used to collect data during salinity surveys as well as methods for data analysis, processing, and production of salinity maps are based on those developed by Halley and others (1995) in their study of salinity patterns in Florida Bay, and later by Byrne and Gabaldon (2008) in their study of salinity patterns in Estero Bay, Florida. Surface-water salinity and temperature were measured throughout the TTI area using moving boat surveys. A flow-through chamber was attached to the transom of a boat to collect water from within $1 \mathrm{ft}$ of the water surface (fig. 2). A water-quality probe was secured within the chamber to measure salinity and temperature data. Water-quality data were logged every 10 seconds by a data recorder that simultaneously logged location information from a Global Positioning System (GPS) unit (fig. 3); the GPS unit 


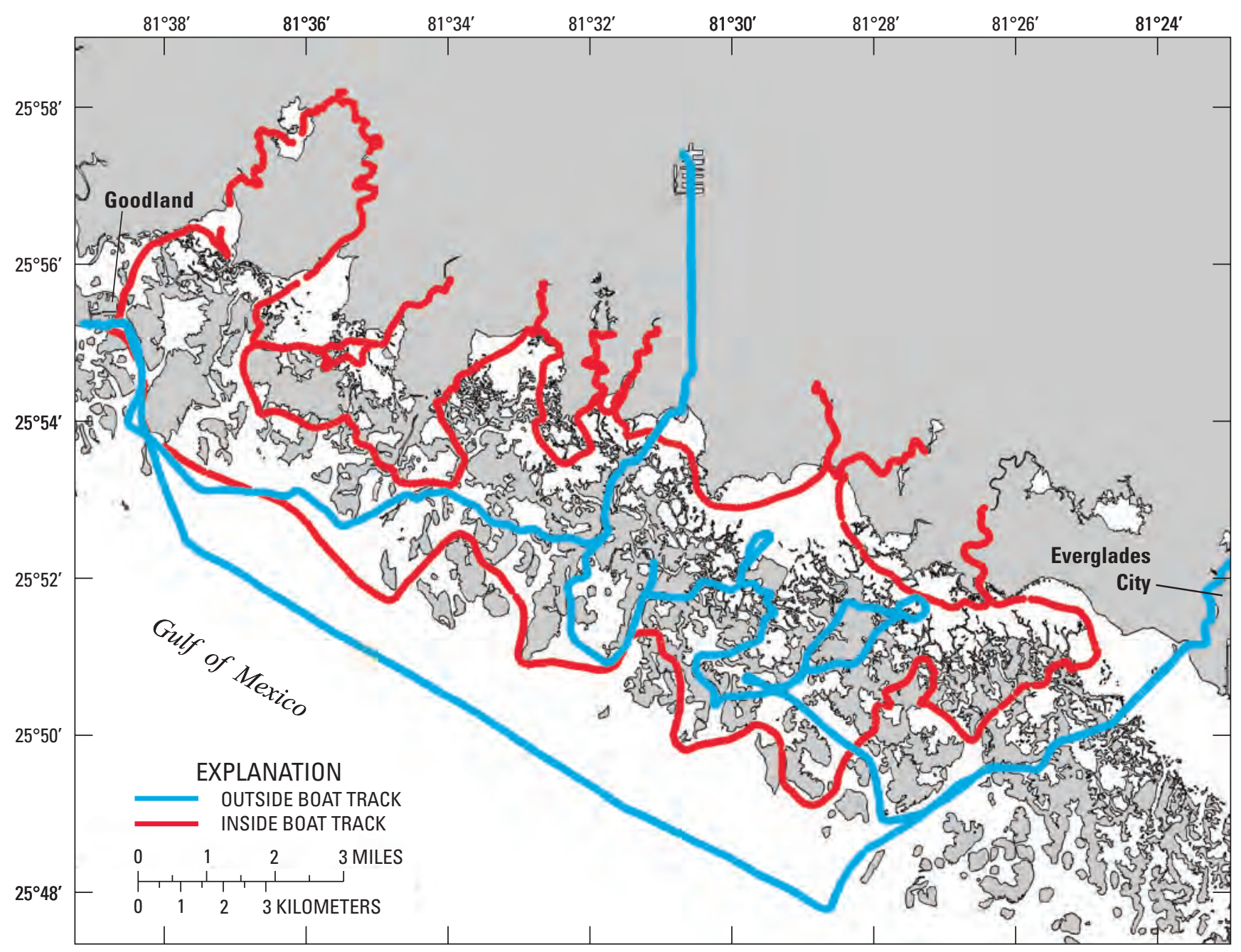

Figure 4. Boat tracks followed during salinity survey. Two boats operate simultaneously on inside and outside tracks to provide greater coverage.

also was used as a navigational aid. Two boats were operated simultaneously to reduce measurement time and increase coverage within a given time period. One boat followed an inside track that covered the estuarine rivers and inner bays and the other followed an outside track that covered the mangrove island region and nearshore Gulf of Mexico boundary (fig. 4). Repeated use of these specific tracks ensured that the same areas were covered during each survey, providing consistency between maps. All surveys began at Goodland, proceeded outbound toward Everglades City along the offshore portion of their respective tracks, and returned along inshore routes. By following this pattern, regions where boat tracks overlapped were traversed with minimal temporal discrepancies. Each survey was performed during high tide to enable travel over areas that were impassable during low tide. The boats traveled at planning speeds averaging of $20 \mathrm{mi} / \mathrm{hr}$, with each survey lasting approximately 5 hours, resulting in a total of 3,000-5,000 samples collected over a distance of $200 \mathrm{mi}$.

Following field collection, data were analyzed to eliminate errors before processing the data and producing the maps. Figure 5A-B shows data from the May 14, 2008, salinity survey before and after editing. Editing consisted of deleting erroneous values caused by air entrapment in the waterquality probe and lost signal from the GPS. Raw and edited 
A. Raw Salinity Data

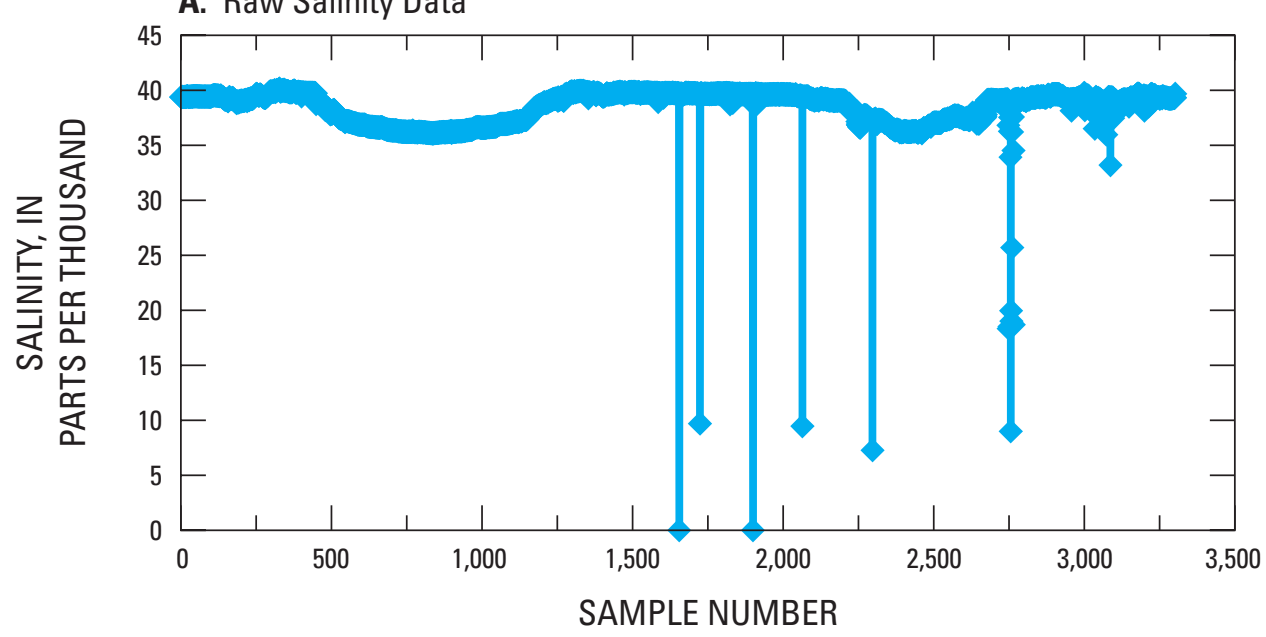

B. Edited Salinity Data

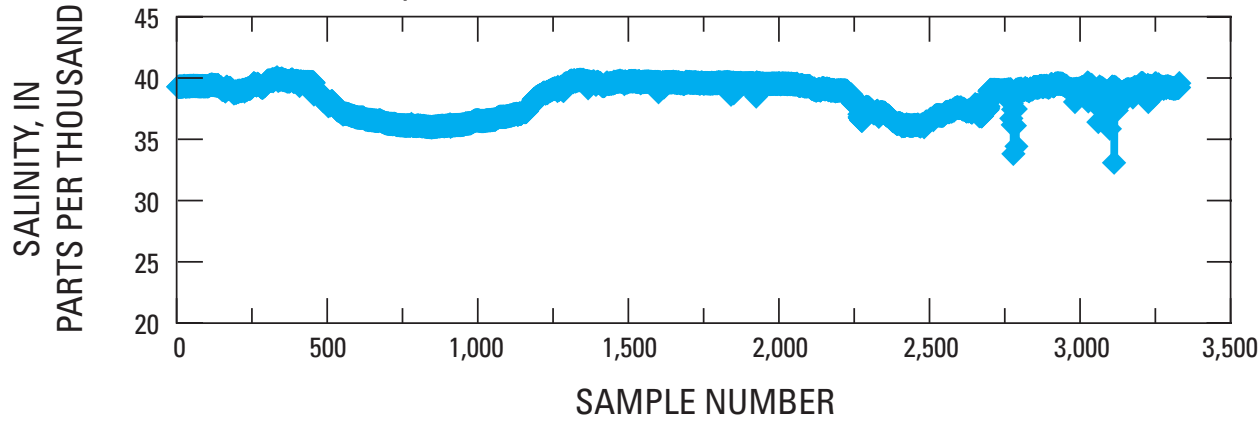

Figure 5. A, Raw salinity data for a single survey performed May 14, 2008, with erroneous readings prior to editing, $B$, Salinity data after editing.

data files were saved to permit further review. The salinity and coordinate data were then imported as point data along transects (for example, data for September 6, 2007; fig. 6) into Environmental Systems Research Institute (ESRI) ArcMap Geographical Information System (GIS) program.

Interpolation was used to convert the point data into a raster layer using the inverse distance weighted (IDW) method within Arc Spatial Analyst, with a distance weighting power of two and variable search radius defined by the 12 closest points. Polyline barriers were digitized to prevent points in one river from being included in the interpolation within an adjacent river (fig. 7). Circulation within the island region of the study area was assumed to be sufficiently adequate for individual islands to not be digitized as barriers to interpolation. The resulting salinity contour raster layer was displayed with an overlaying land layer map to define physical features such as islands and rivers. Ten salinity maps were created from the salinity surveys performed during the period from May 10, 2007, through May 7, 2009. 


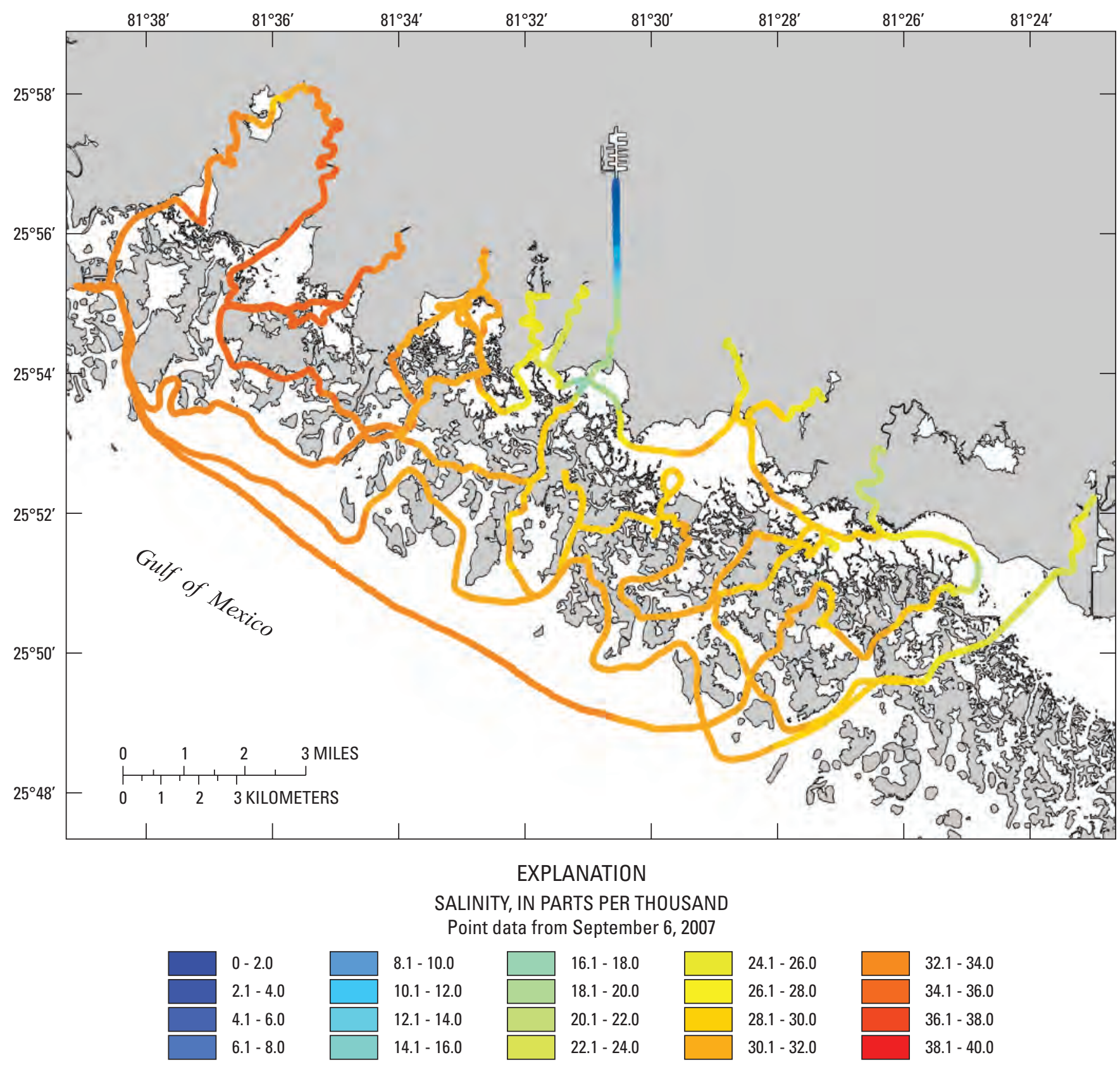

Figure 6. Point data collected during the September 6, 2007, salinity survey. 


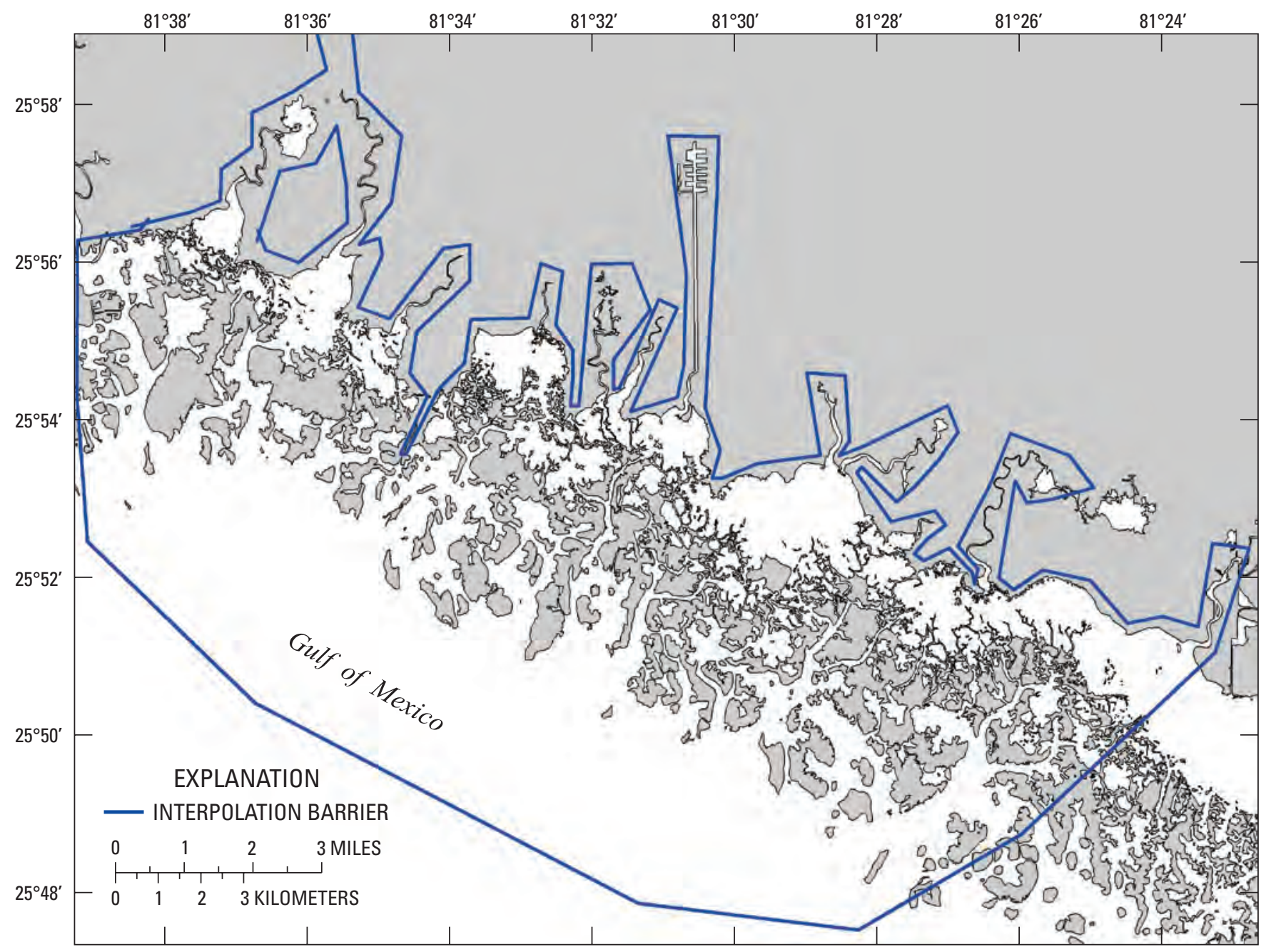

Figure 7. Barriers used to prevent interpolation between adjacent but independent water bodies during generation of raster layers using the inverse distance weighted function. 


\section{Seasonal and Spatial Distribution of Freshwater Flow and Salinity}

The salinity maps presented in figures $8-17$ captured the point discharge of freshwater into the TTI estuary from the Faka Union Canal system and Barron River Canal. Excluding the peak of the dry season (figs. 8, 13, and 17) and wet season (fig. 15), the lowest salinities either occurred within Faka Union Canal and Faka Union Bay (fig. 9), Barron River and Chokoloskee Bay (figs. 12 and 16), or both (figs. 10, 11, and 14). During 2008, the mean monthly wet season (June - October) flow at the mouth of the Faka Union Canal was $805 \mathrm{ft}^{3} / \mathrm{s}$, nearly ten times more than at Little Wood River $\left(93 \mathrm{ft}^{3} / \mathrm{s}\right)$ and East River $\left(87 \mathrm{ft}^{3} / \mathrm{s}\right)($ table 1$)$.

The diversity and density of submerged aquatic vegetation, fish, and benthic organisms are less in Faka Union Bay than in neighboring Fakahatchee Bay (Sklar and Browder, 1998). Because many of these species cannot tolerate wide fluctuations in salinity, the differences were attributed, in part, to the rapid salinity fluctuations that occurred in Faka Union Bay from pulse discharge of freshwater following rain events. A hydrologic model of salinity isohalines within Faka Union Bay as a function of Faka Union Canal discharge indicated that the canal reduced salinity below the range favorable for fishes (Browder and Wang, 1987).

During the 2007 wet season (figs. 10 and 11), salinities were highest in the inner bays west of Faka Union Bay. The northern part of the watershed for this region was reduced in size by construction of the Faka Union Canal System (fig. 1). Freshwater enters this part of the estuary as rainfall or as runoff from rainfall within a few miles north and south of U.S. 41 . During this same time period, salinities within the inner bays east of Faka Union Bay were 2-4 ppt lower than within the inner bays further west. Available pathways for sheetflow under U.S. 41 are fairly consistent across this entire region, averaging 3-4 bridges and/or culverts per mile. However, the northern portion of the watershed for this region (east of Faka Union Bay) is Fakahatchee Strand Preserve State Park, which is relatively pristine (fig. 1). Rainfall runoff anywhere within this region can potentially flow south toward the estuary after passing beneath bridges and culverts along U.S. 41 .
During the 2008 wet season, salinities in Pumpkin Bay were higher than in neighboring bays (figs. 14 and 15) by 2-4 ppt. The hypersaline conditions are due in part to the poor hydraulic connection between the Bay and interior wetlands through Pumpkin River. During 2008, the mean monthly wet season flow at Pumpkin River was only $5 \mathrm{ft}^{3} / \mathrm{s}$, compared to $93 \mathrm{ft}^{3} / \mathrm{s}$ at neighboring Little Wood River, and $58 \mathrm{ft}^{3} / \mathrm{s}$ at Blackwater River (table 1). In addition, Pumpkin Bay is shallow (1.5-2.0 ft deep at mean low tide), which promotes freshwater evaporation from Gulf of Mexico waters that enter the Bay during flood tide. Hypersaline conditions have been documented in Pumpkin Bay in past studies, such as Browder and others (1989).

Entrapment of high-salinity water within the shallow inner bays was not limited to Pumpkin Bay. At the peak of the 2007 and 2008 dry seasons (figs. 8, 13, and 17), the lack of freshwater entering the estuary, combined with evaporation, resulted in hypersaline conditions throughout the entire study area. Among the hypersaline areas was Fakahatchee Bay, which had been identified in previous research (Browder and others, 1986) to have salinity patterns comparable to predrainage conditions. The variability within the hypersaline area for May 14, 2008, is shown in figure 18 using a scale that highlights this feature. Hypersaline conditions were also present within Faka Union Canal and Barron River during this time.

Seasonal rainfall affects salinity patterns in the TTI estuary substantially, as indicated by the differences between wet season conditions for 2007 (fig. 10 and 11) and 2008 (fig. 15). The TTI watershed received 9 more iches of rainfall during the 2008 wet season (July-September) compared to the 2007 wet season (fig. 19). Rainfall was augmented by Tropical Storm Fay, which deposited 6-8 in. of rainfall as it passed through the region on August 18-19, 2008 (National Oceanic and Atmospheric Administration, 2008). Salinities within the inner bays, mangrove island region, and nearshore Gulf of Mexico, were 8-16 ppt, 6-10 ppt, and 4-8 ppt fresher, respectively, during 2008 (fig. 15) than 2007 (fig. 10 and 11) as a result of the additional rainfall. During both periods, salinities were lower in Faka Union Bay than in other inner bays. On September 25, 2008, the low-salinity water from Faka Union Bay extended eastward into neighboring Fakahatchee Bay (fig. 15).

Table 1. Wet and dry season discharge at USGS monitoring stations in the Ten Thousand Islands, January - December 2008.

[Values are in cubic feet per second]

\begin{tabular}{lccccc}
\hline \multicolumn{1}{c}{ Season } & $\begin{array}{c}\text { Blackwater } \\
\text { River }\end{array}$ & $\begin{array}{c}\text { Pumpkin } \\
\text { River }\end{array}$ & $\begin{array}{c}\text { Little } \\
\text { Wood } \\
\text { River }\end{array}$ & $\begin{array}{c}\text { Faka Union } \\
\text { Canal } \\
\text { (at mouth) }\end{array}$ & $\begin{array}{c}\text { East } \\
\text { River }\end{array}$ \\
\hline Wet Season (Jun.-Oct.) & 58 & 5 & 93 & 805 & 87 \\
Dry Season (Jan.-May; Nov.-Dec.) & -27 & 0 & -9 & 1 & -7 \\
\hline
\end{tabular}




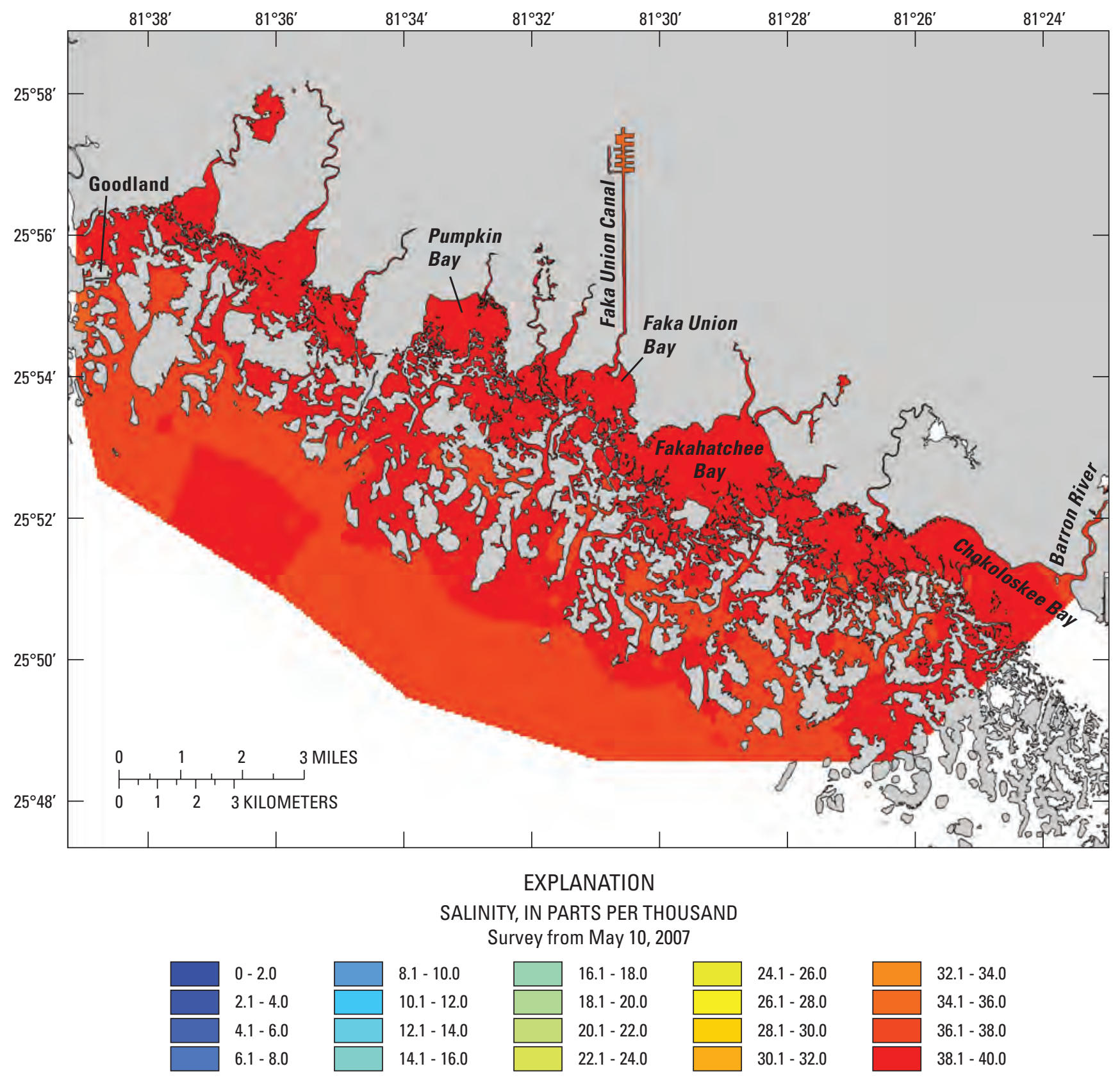

Figure 8. Salinity patterns in the Ten Thousand Islands during end of dry season on May 10, 2007. 


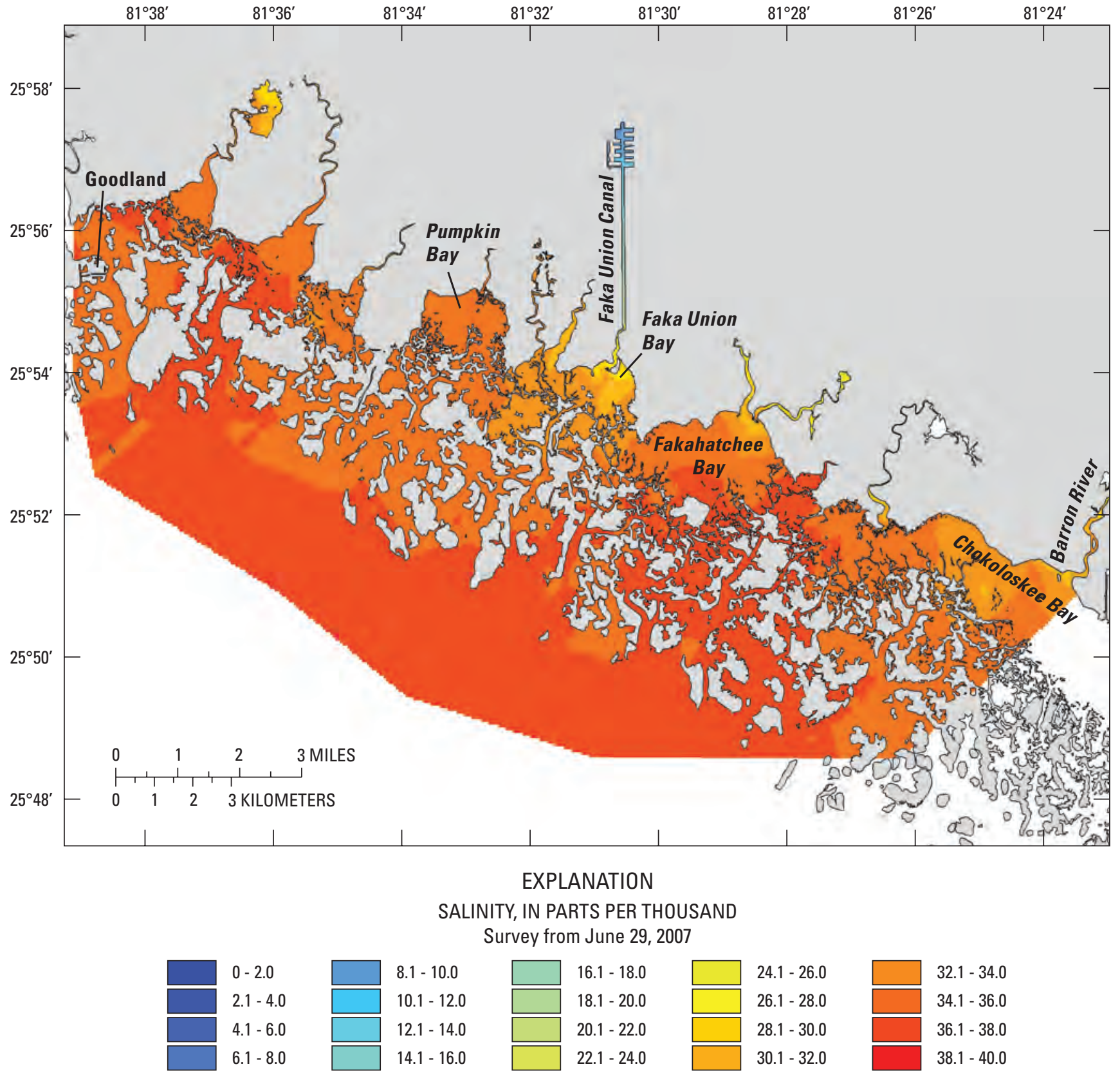

Figure 9. Salinity patterns in the Ten Thousand Islands during transition to wet season on June 29, 2007. 


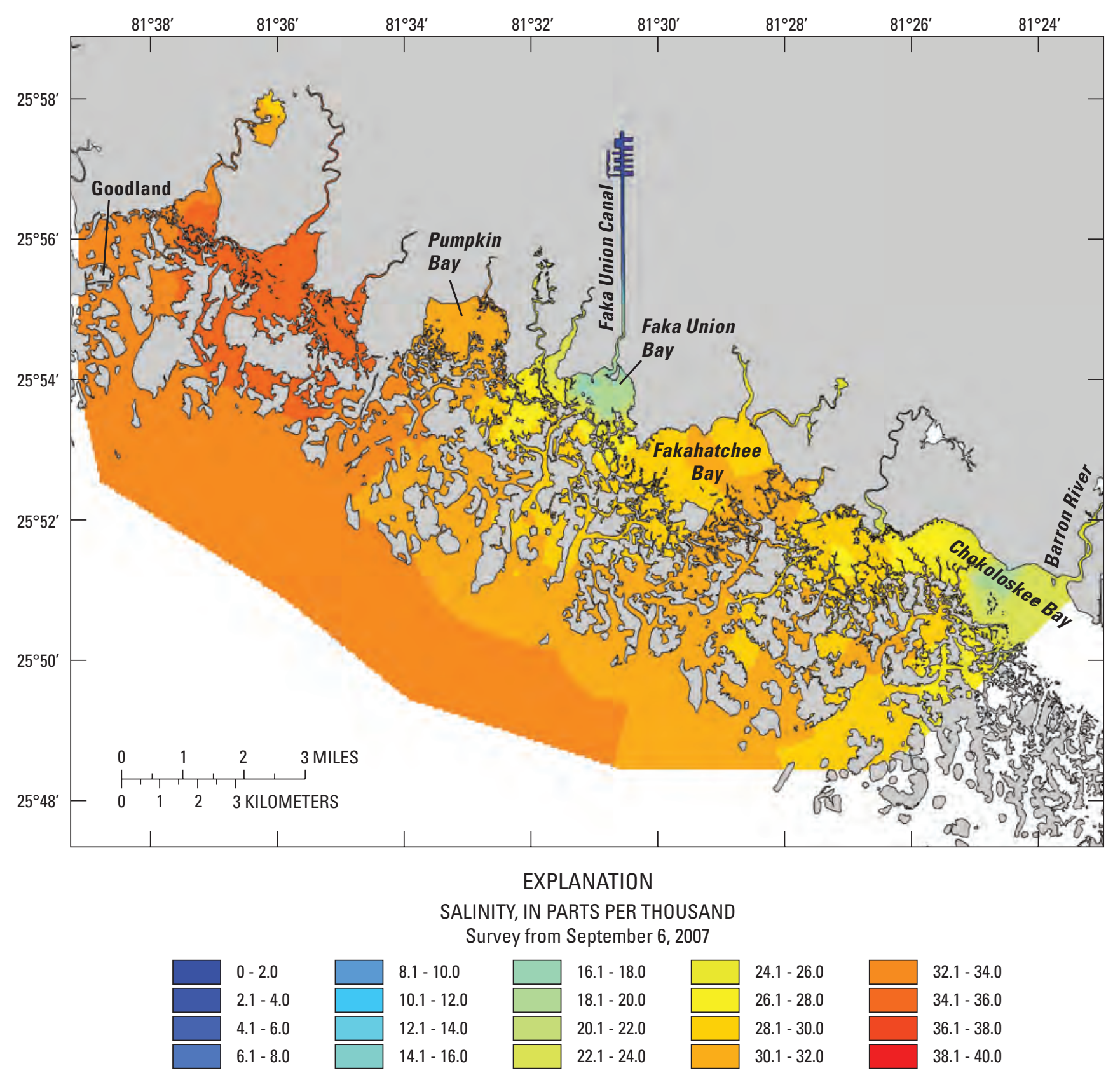

Figure 10. Salinity patterns in the Ten Thousand Islands during middle of wet season on September 6, 2007. 


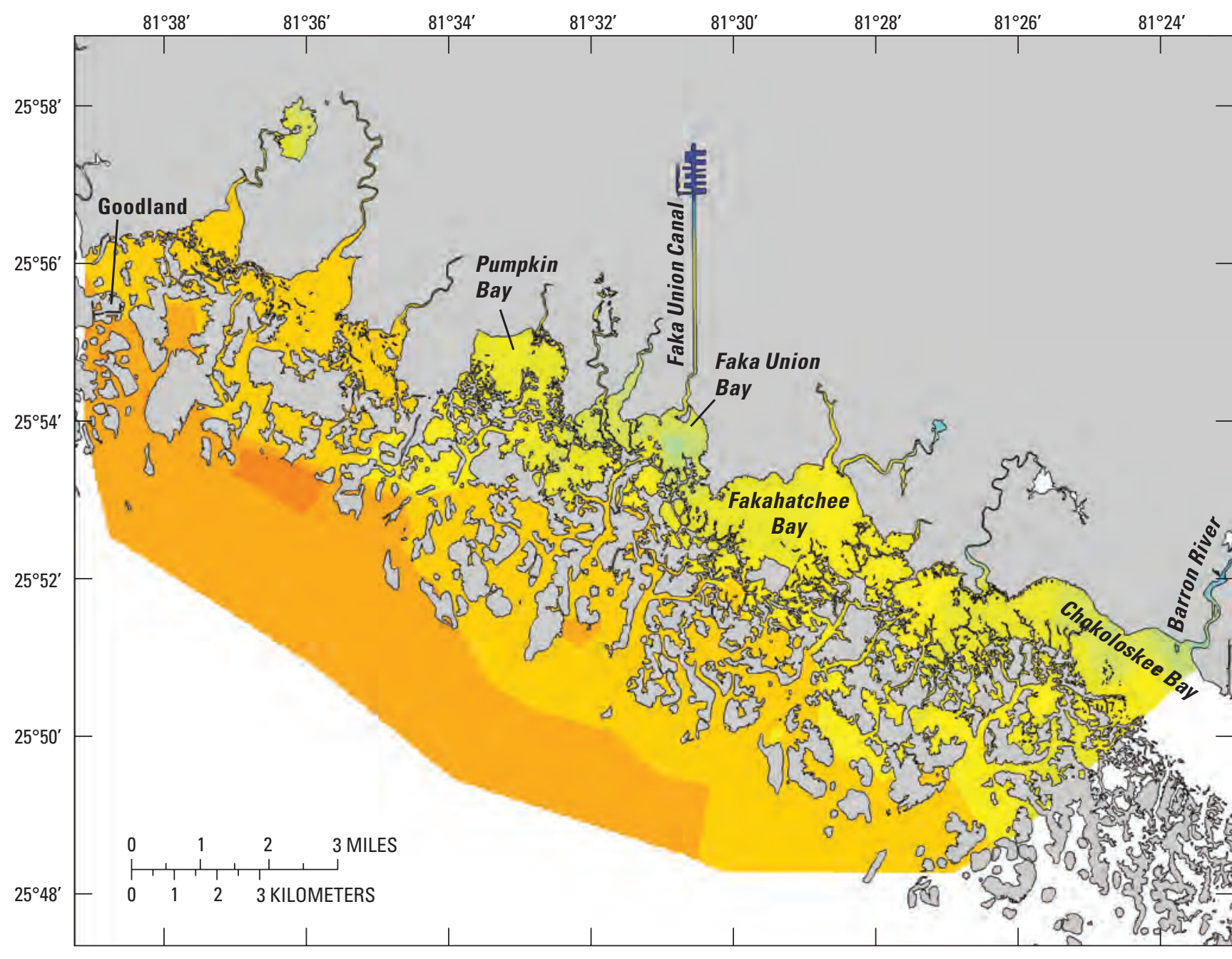

\section{EXPLANATION}

SALINITY, IN PARTS PER THOUSAND

Survey from October 23, 2007

\begin{tabular}{|c|c|c|c|c|}
\hline $0-2.0$ & $8.1-10.0$ & $16.1-18.0$ & $24.1-26.0$ & $32.1-34.0$ \\
\hline $2.1-4.0$ & $10.1-12.0$ & $18.1-20.0$ & $26.1-28.0$ & $34.1-36.0$ \\
\hline $4.1-6.0$ & $12.1-14.0$ & $20.1-22.0$ & $28.1-30.0$ & $36.1-38.0$ \\
\hline $6.1-8.0$ & $14.1-16.0$ & $22.1-24.0$ & $30.1-32.0$ & $38.1-40.0$ \\
\hline
\end{tabular}

Figure 11. Salinity patterns in the Ten Thousand Islands during middle of wet season on October 23, 2007. 


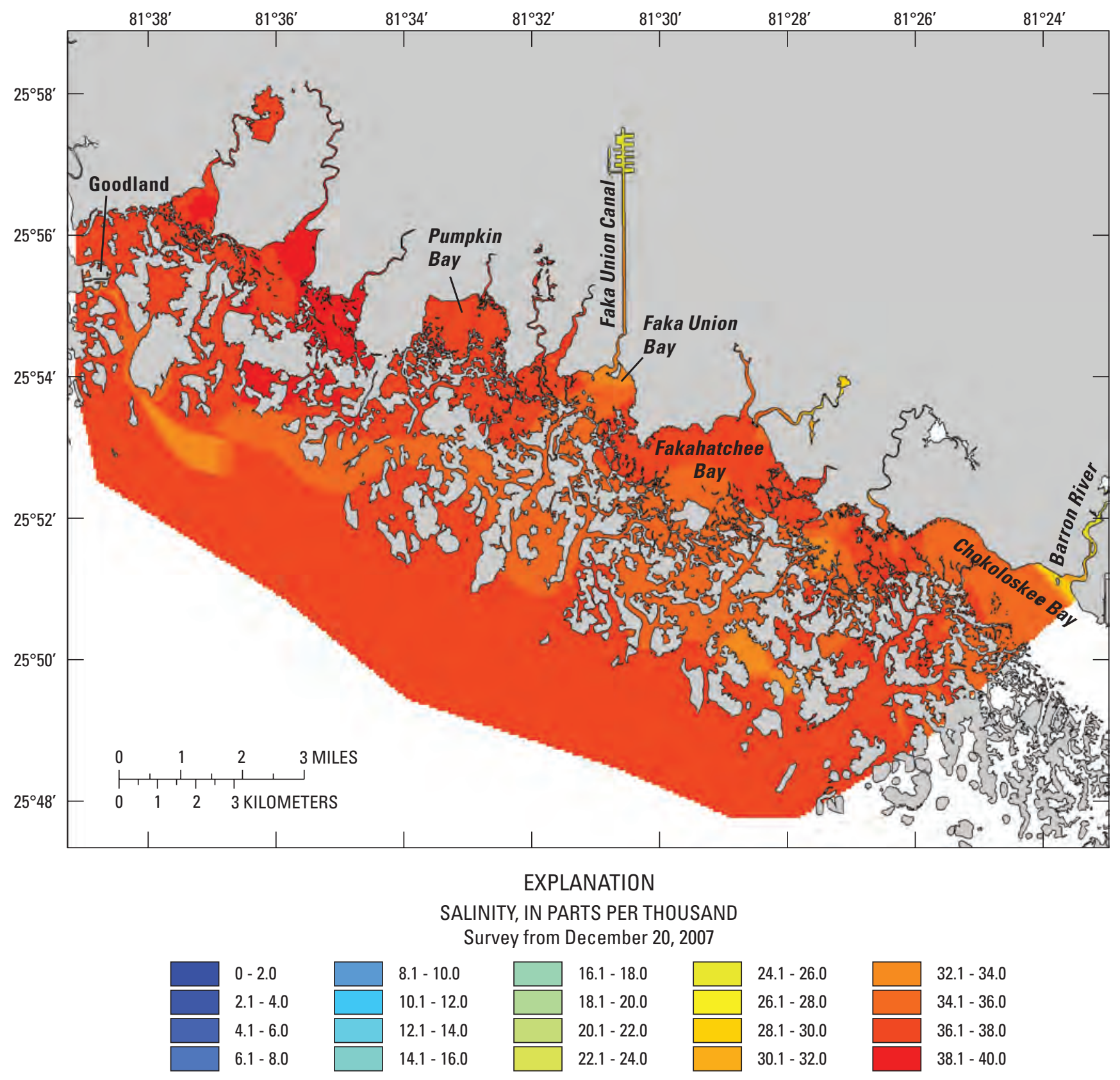

Figure 12. Salinity patterns in the Ten Thousand Islands during transition to dry season on December 20, 2007. 


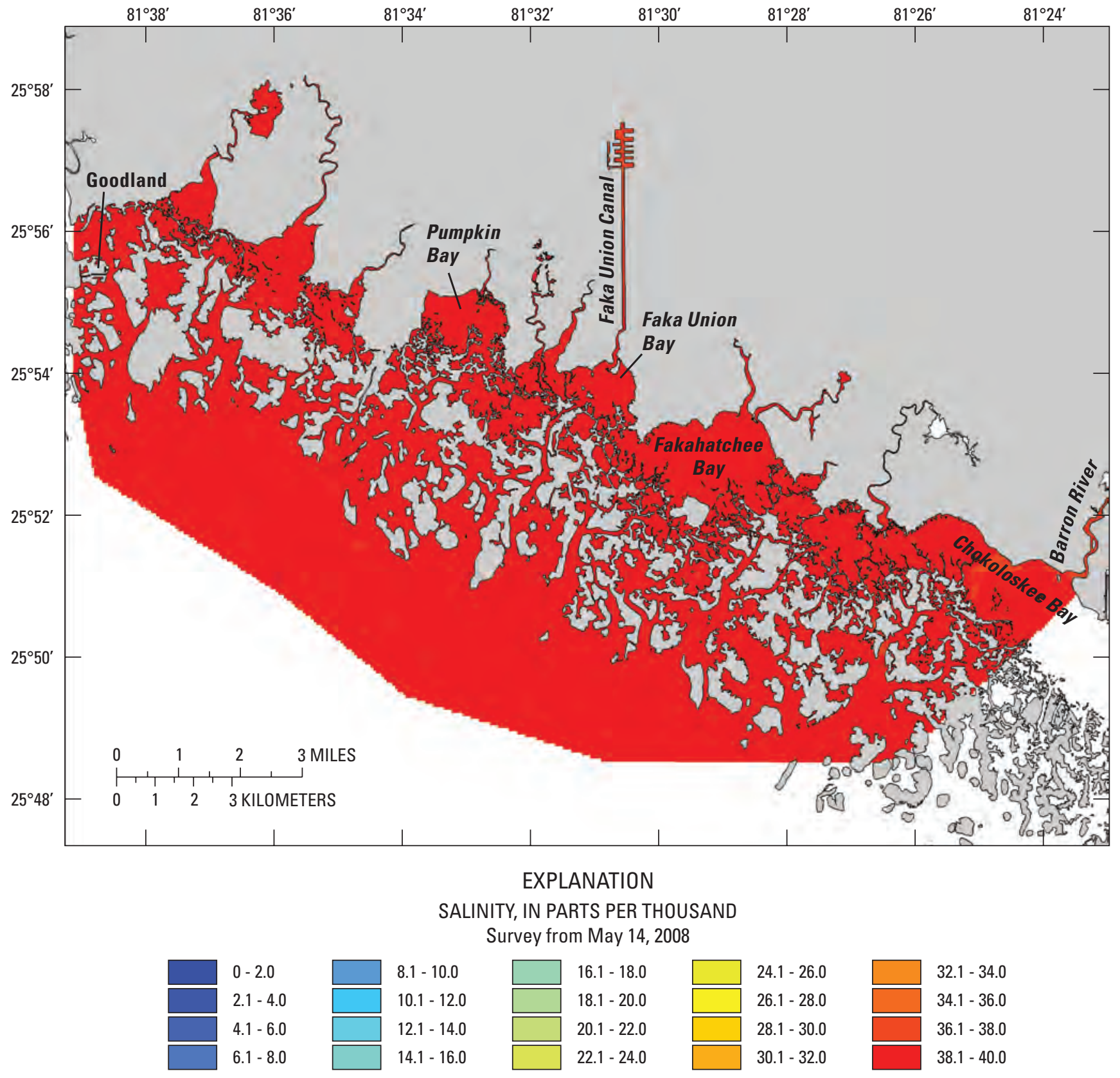

Figure 13. Salinity patterns in the Ten Thousand Islands during end of dry season on May 14, 2008. 


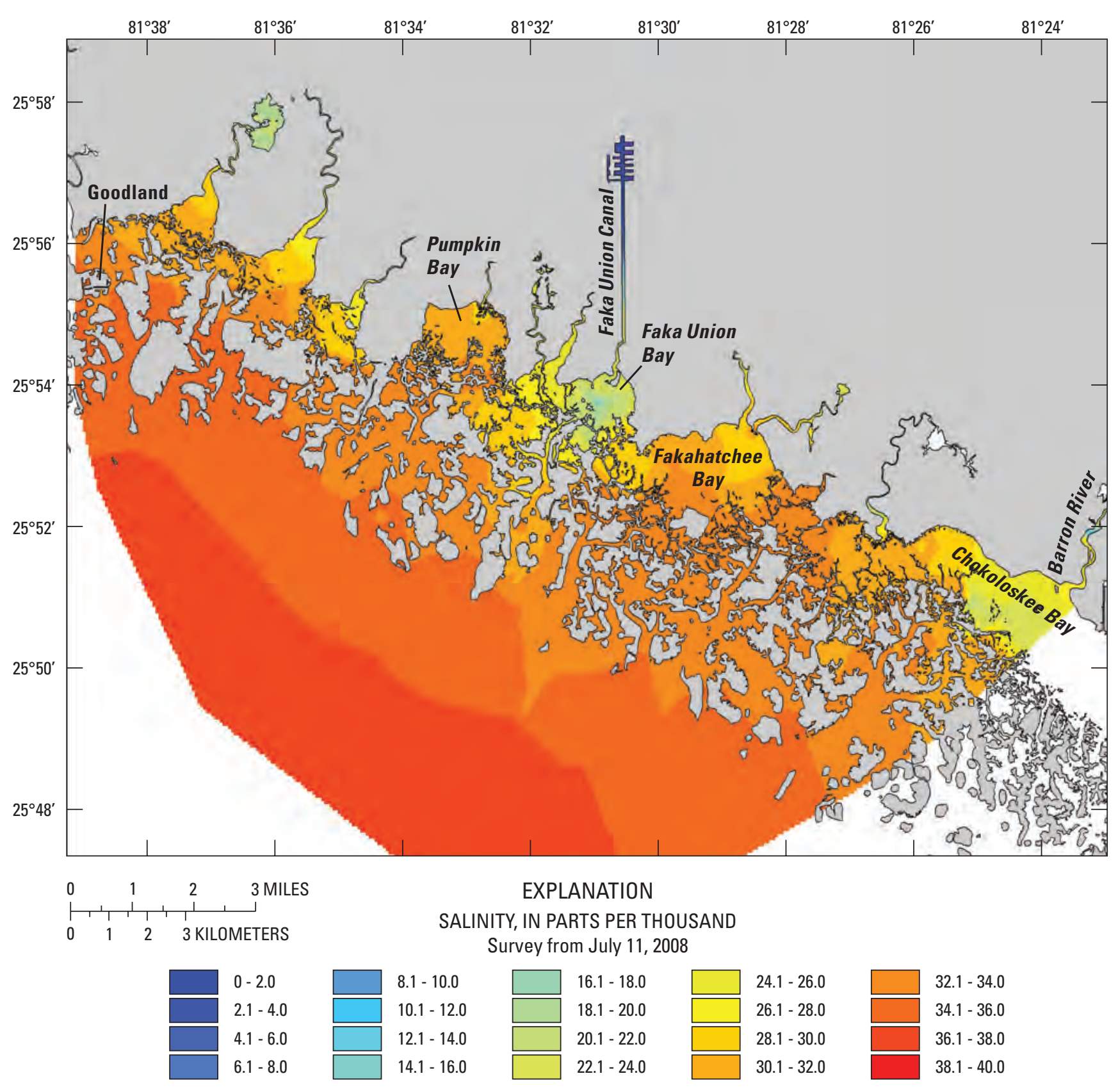

Figure 14. Salinity patterns in the Ten Thousand Islands during transition to wet season on July 11, 2008. 


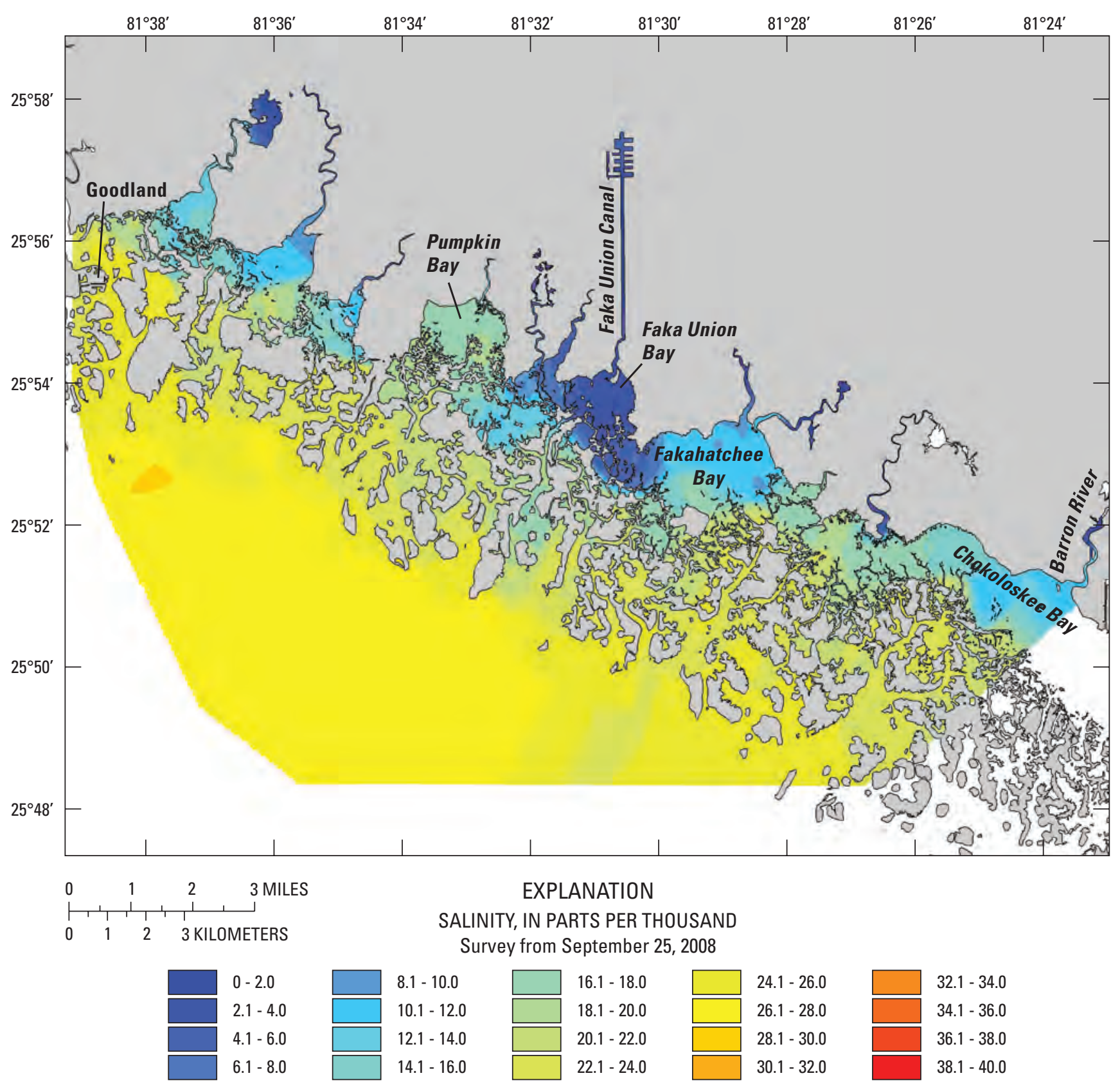

Figure 15. Salinity patterns in the Ten Thousand Islands during middle of wet season on September 25, 2008. 


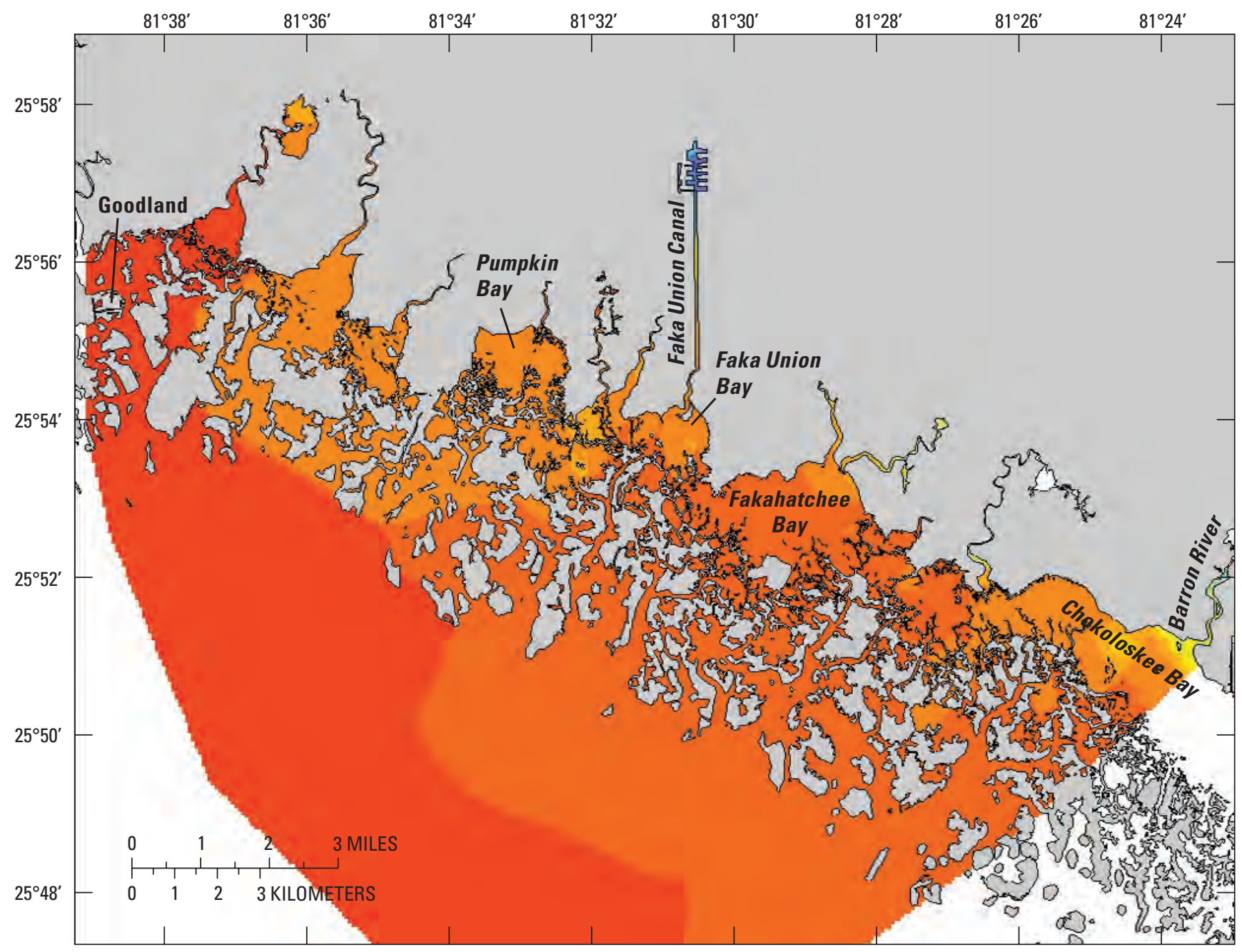

EXPLANATION

SALINITY, IN PARTS PER THOUSAND

Survey from January 8, 2009

\begin{tabular}{l}
$0-2.0$ \\
\hline$\square .1-4.0$ \\
$4.1-6.0$ \\
$6.1-8.0$
\end{tabular}

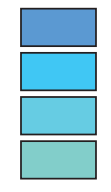

$8.1-10.0$
$10.1-12.0$
$12.1-14.0$
$14.1-16.0$

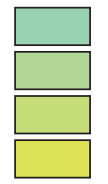

$16.1-18.0$
$18.1-20.0$
$20.1-22.0$
$22.1-24.0$

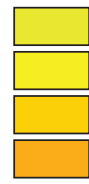

$24.1-26.0$

$26.1-28.0$

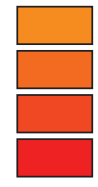

$32.1-34.0$

$34.1-36.0$

$36.1-38.0$

$38.1-40.0$

Figure 16. Salinity patterns in the Ten Thousand Islands during transition to dry season on January 8, 2009. 


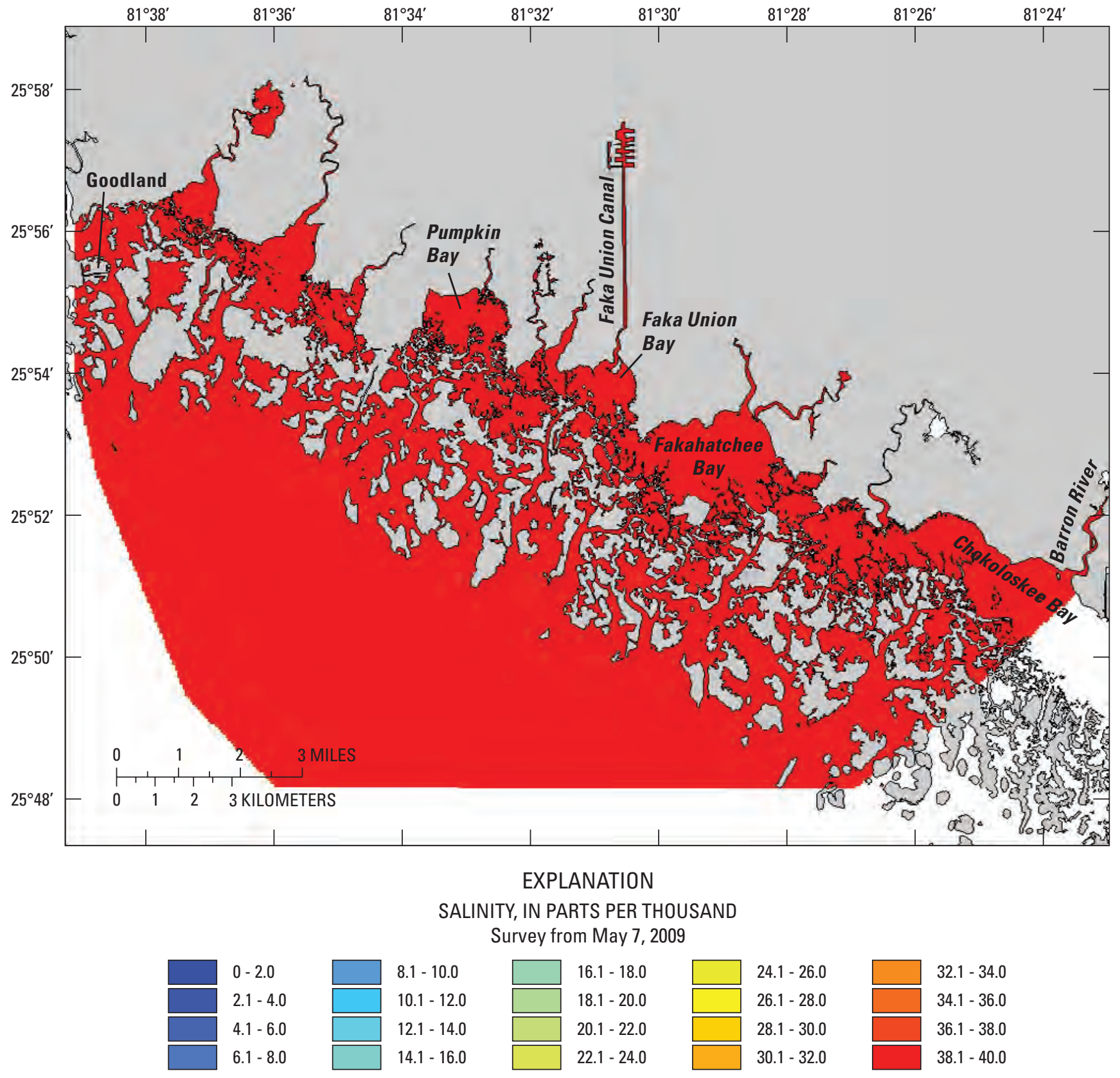

Figure 17. Salinity patterns in the Ten Thousand Islands during end of dry season on May 7, 2009. 


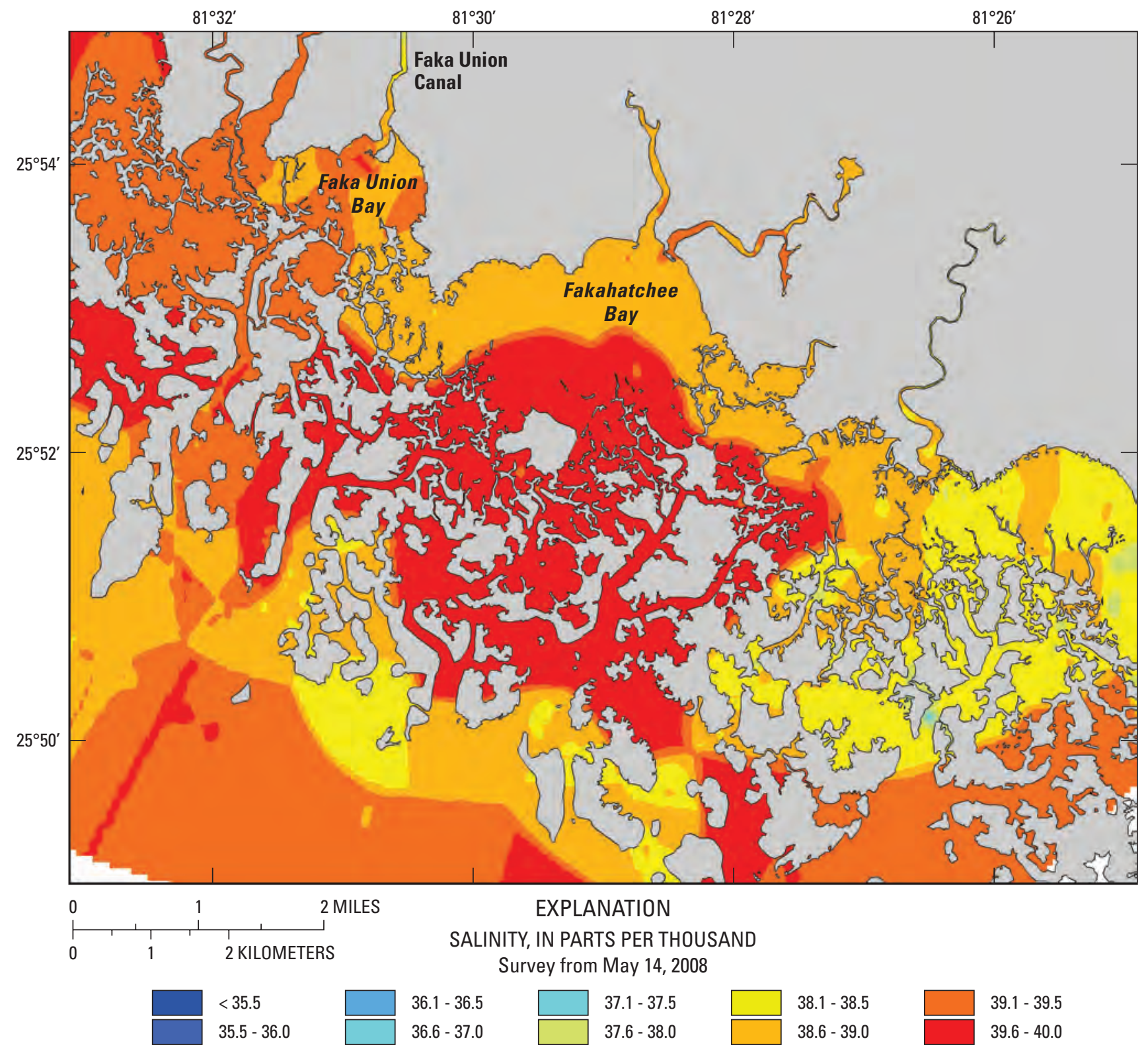

Figure 18. Salinity patterns in and around Fakahatchee Bay on May 14, 2008. The salinity scale for this map differs from the preceding maps, and is used here to emphasize high salinities. 


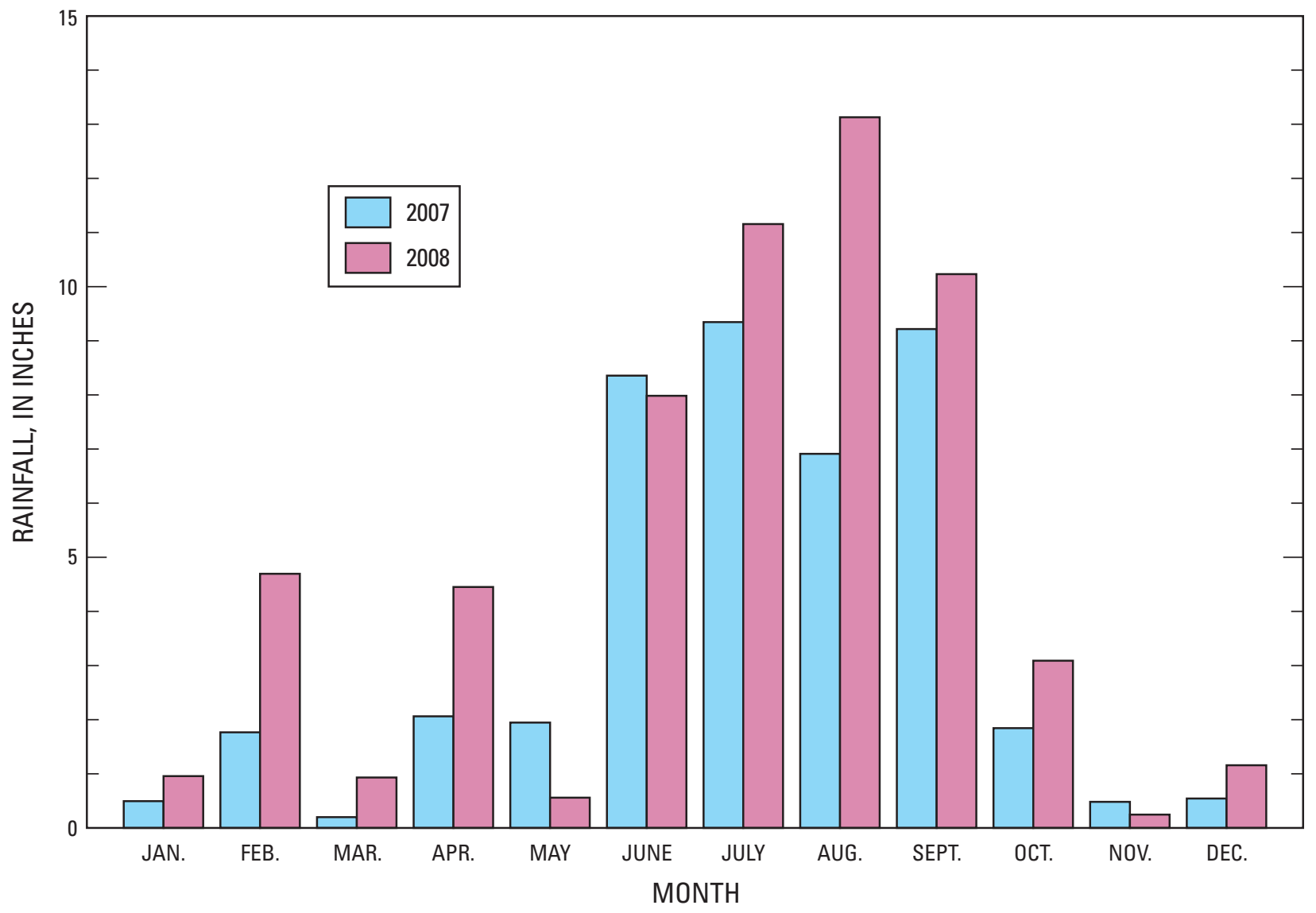

Figure 19. Rainfall in the Ten Thousand Islands watershed during 2007 and 2008, as measured by the South Florida Water Management District. Data are a mean of FKSTRN, DANHP, SGGEWX, and COLLISEM stations obtained from the South Florida Water Management District DBHYDRO database. 


\section{Limitations of the Salinity Maps}

Salinity surveys were only performed during high tide to avoid the shallow water and exposed oyster bars that constrain travel during low tide. In addition, salinity measurements were only made within $1 \mathrm{ft}$ of the surface. As a result, the salinity maps do not account for tidal variations or vertical stratification, both of which can be quite substantial during the wet season. Salinity data from four stations in the monitoring network collected during and near the period of the July 11,2008 , salinity survey indicate that surface salinity varied by as much as 15 ppt during a tidal cycle (fig. 20). During that same time period, surface salinity was $2-3 \mathrm{ppt}$ less than bottom salinity in Blackwater River due to vertical stratification (fig. 21).

The survey routes used by the two boats were designed such that where boat tracks overlapped, they were traversed with minimal lag time. Nonetheless, temporal discrepancies were unavoidable, which may have generated small discontinuities in the maps due to tidal variations in salinity. Although each map has inherent associated errors, the error between maps was reduced by minimizing as much variation between surveys as possible (for example, survey paths, timing with tides).

\section{Summary}

The construction of roads and canals within the watershed of the TTI estuary has altered freshwater delivery to the estuary, reducing freshwater flows to some areas and producing excessive flows in other areas. Two restoration projects have been implemented to improve freshwater delivery to the system. To monitor the effects of these restoration projects, the USGS initiated a study in October 2006 that included periodic salinity mapping of the TTI estuary.

Surface salinity and position data were collected throughout the TTI estuary using moving boat surveys. IDW interpolation was used to convert the point data into salinity contour maps of the entire region. Surveys were performed approximately four times a year, during the height of the dry season, transition to wet season, height of the wet season, and transition to dry season. Data for the ten salinity maps presented herein were collected between May 2007 and May 2009.

The salinity maps presented herein illustrate that modifications to the watershed have affected salinities within the estuary. All maps except those created during the peak of the dry season indicate that freshwater discharge from the Barron River Canal reduced salinities in Barron River and Chokoloskee Bay. Similarly, freshwater discharge from the Faka Union Canal system reduced salinities in Faka Union Bay during all periods except the peak of the dry season. Faka Union Canal discharge appears to affect salinities in neighboring Fakahatchee Bay and Little Wood Rivers as well, although to a lesser extent. Past research suggests that rapid salinity fluctuations caused by Faka Union Canal discharge may be harmful to submerged aquatic vegetation, fish, and benthic organisms.

The watershed of the western TTI estuary was reduced by the construction of roads and canals for the SGGE development. In contrast, the watershed of the eastern TTI estuary lies within the Fakahatchee Strand State Preserve and has remained relatively pristine. This disparity is apparent in salinity maps generated during the 2007 wet season, which show greater salinity in the inner bays west of the Faka Union Canal, including Pumpkin Bay, than in the inner bays east of the Faka Union Canal.

Lack of rainfall, combined with high rates of evaporation within the shallow estuary, can cause hypersaline conditions to develop during the dry season. Salinity maps produced during the peak of the dry season for each year (2007-2009) indicate hypersaline conditions exist throughout the entire estuary, including Faka Union Bay and Barron River.

Seasonal rainfall, augmented by Tropical Storm Fay, substantially lowered salinities throughout the entire estuary and nearshore Gulf of Mexico area during the peak of the 2008 wet season. The estuary remained much more saline during the drier 2007 wet season. Year-to-year variability in rainfall, coupled with precipitation from tropical systems, can substantially affect salinity in the estuary.

The salinity maps presented herein describe surface salinity during high tide, and therefore, cannot account for variability caused by ebb/flood tides and vertical stratification. Because this limitation is common to all of the salinity maps, the inherent variability between maps is reduced. The strength of the maps is their ability to describe salinities over the entire system, including unmonitored areas.

As previously noted, the goal of the PSRP is to "restore historic hydroperiods and sheetflow patterns in the study area to the extent possible, while maintaining the existing levels of flood protection for areas north of the SGGE" (U.S. Army Corps of Engineers, 2004). This restoration to the watershed of the western TTI may result in more evenly distributed and prolonged freshwater discharge to the TTI estuary. The salinity maps, coupled with data from the monitoring stations, provide baseline information of seasonal and spatial distribution of freshwater flow and salinity in the TTI estuary, and a means of monitoring the effects of restoration in improving freshwater delivery to the estuary.

\section{Acknowledgments}

The authors wish to thank the Fort Myers, Florida, USGS personnel for their dedication in making this monitoring effort possible, including Craig Thompson, Andrew Erickson, Noel Wingers, Marty Berry, and Amanda Booth, all of whom spent many hours boating through the TTI estuary collecting the salinity data presented in this report. 


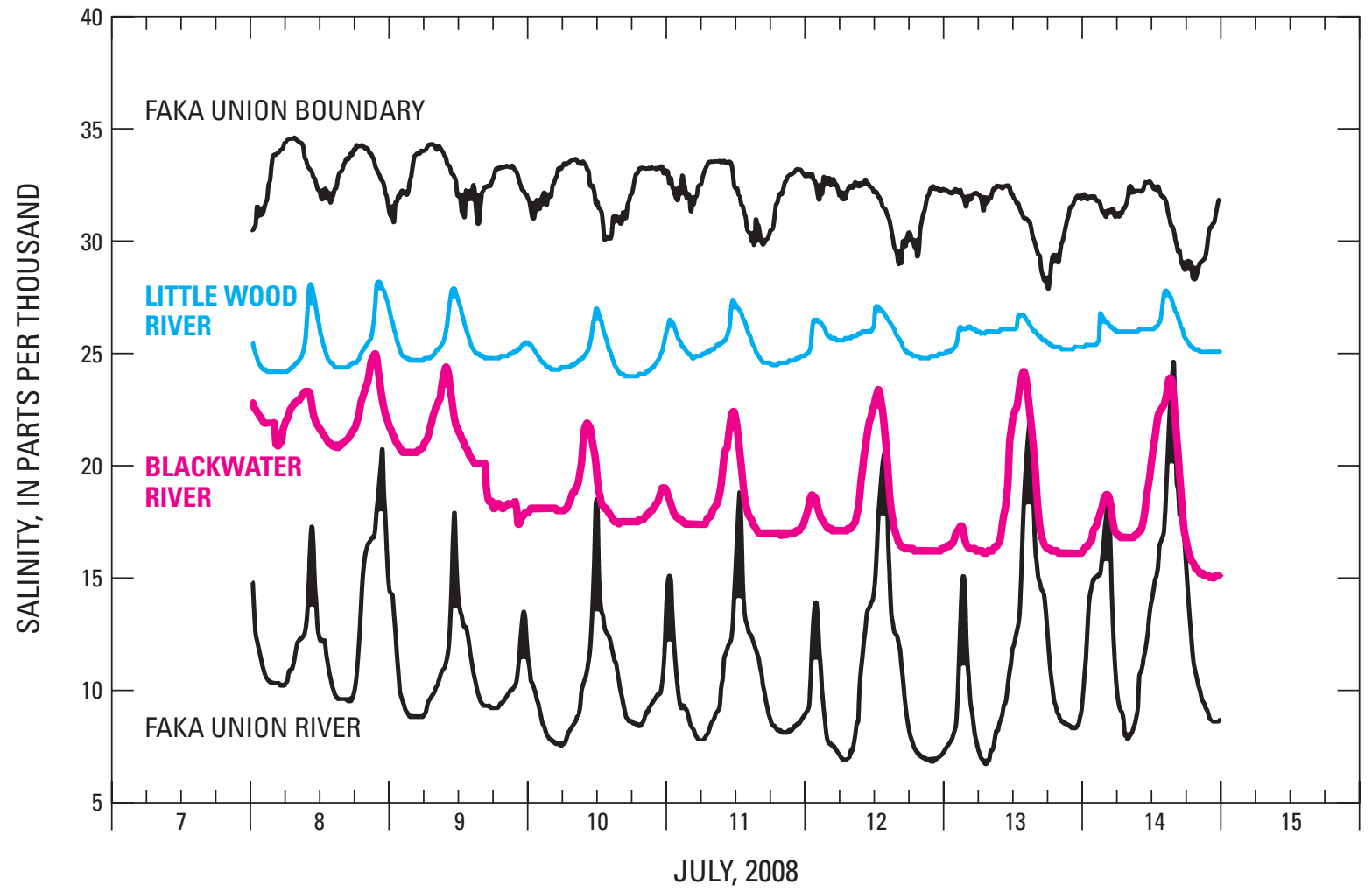

Figure 20. Surface salinities at four U.S. Geological Survey monitoring stations on and around the July 11, 2008 salinity survey.

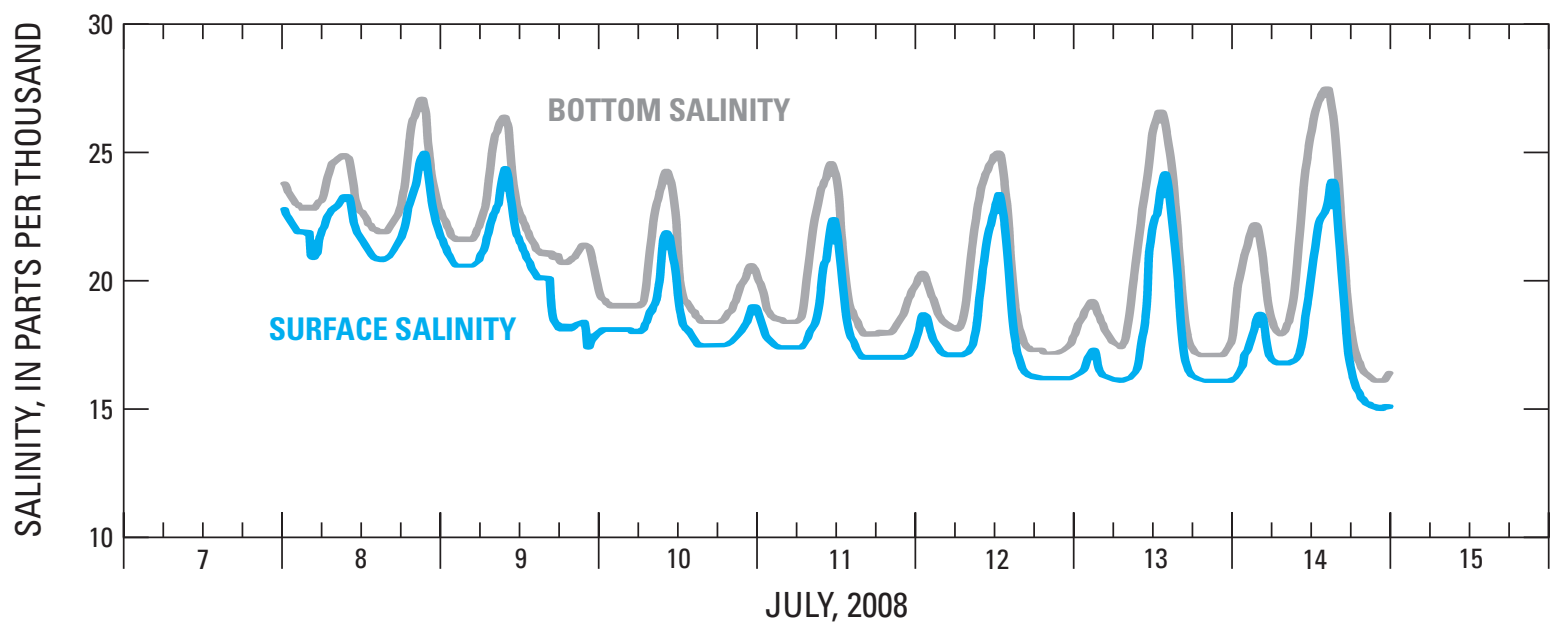

Figure 21. Surface and bottom salinities at the Blackwater River monitoring station on and around the July 11, 2008 salinity survey. 


\section{References Cited}

Browder, J.A., Dragovich, Alexander, Tashiro, J.E., ColemanDuffie, Essie, Foltz, Greg, and Zweifel, James, 1986, A comparison of biological abundances in three adjacent bay systems downstream from the Golden Gate Estates canal system: National Oceanic and Atmospheric Administration Technical Memorandum NMFS-SEFC-185, 26 p.

Browder, J.A., Tashiro, J.E., Coleman-Duffie, Essie, Rosenthal, D.A., and Wang, J.D., 1989, Documenting estuarine impacts of freshwater alterations and evaluating proposed remedies, in Proceedings of the International Wetland Symposium, July 5-9, 1989, Charleston, South Carolina.

Browder, J.A., and Wang, J.D., 1987, Modeling water management effects on marine resource abundances in Faka Union Bay, Florida: Proceedings of Symposium on the Ecology and Conservation of Wetlands of the Usumacinta and Grijalva Delta, Villahermosa, Tabasco, Mexico, February 2-6, 1987.

Byrne, M.J., and Gabaldon, J.N., 2008, Hydrodynamic characteristics and salinity patterns in Estero Bay, Lee County, Florida: U.S. Geological Survey Scientific Investigations Report 2007-5217, 33 p., available online at: http://pubs. usgs.gov/sir/2007/5217.

Decker, J.D., Swain, Eric, Stith, B.M., and Langtimm, C.A., 2008, Predicting hydrologic changes to West Indian Manatee habitats in Southwest Florida due to proposed restoration projects [abs.], in Lavoie, D.L., Rosen, B.H., and others, eds., USGS Gulf Coast Science Conference and Florida Integrated Science Center Meeting: Proceedings with Abstracts, October 20-23, 2008, Orlando, Florida: U.S. Geological Survey Open File Report 2008-1329, p. 103 .

Halley, Robert, Smith, Dewitt, and Hansen, M.E., 1995, Surface salinity of Florida Bay: U.S. Geological Survey Open-File Report 95-634, available online at: http://sofia. usgs.gov/publications/ofr/95-634/index.html.

National Oceanic and Atmospheric Administration, 2008, Event record details: National Climatic Data Center, accessed January 2009 at http://www4.ncdc.noaa.gov/cgiwin/wwcgi.dll?wwevent ShowEvent 739501 .
Sklar, F.H., and Browder, J.A., 1998, Coastal environmental impacts brought about by alterations to freshwater flow in the Gulf of Mexico: Environmental Management, v. 22, p. $547-562$.

South Florida Water Management District, 2006, Quick facts on Barron River (SR29) Canal Corridor Aerial Mapping and Survey Project: Accessed May 2009 at http://www. sfwmd.gov/pls/portal/docs/PAGE/PG_GRP_SFWMD_ REGIONALSERV/PORTLET_BCBPROJECTS/SR29_ FACT_SHEET.PDF.

South Florida Water Management District Big Cypress Basin and U.S. Department of Agriculture Natural Resources Conservation Service, 2003, Southern Golden Gate Estates watershed planning assistance cooperative study: Final Report, October 2003, 108 p.

Summers, J.K., 1999, The ecological condition of estuaries in the Gulf of Mexico: U.S. Environmental Protection Agency report EPA 620-R-98-004, Gulf Breeze, Florida, 96 p.

Swain, Eric, and Decker, Jeremy, 2009, Development, testing, and application of a coupled hydrodynamic surface-water/ ground-water model (FTLOADDS) with heat and salinity transport to support ecosystem restoration in the TenThousand Islands/Picayune Strand Restoration Project Area, Florida: U.S. Geological Survey Scientific Investigations Report 2009-5146.

U.S. Army Corps of Engineers, 1998, Central and Southern Florida Ecosystem Restoration Project Letter Report: Tamiami Trail Culverts: Accessed February 2005 at: http://www.saj.usace.army.mil/projects/tamtrep.htm.

U.S. Army Corps of Engineers, 2004, Picayune Strand Restoration Project (formerly Southern Golden Gate Estates Ecosystem Restoration): Final Integrated Project Implementation Report and Environmental Impact Statement, Jacksonville, Florida, 414 p.

U.S. Army Corps of Engineers, 2008, Picayune Strand Restoration Facts \& Information: Accessed October 2008 at http:// www.evergladesplan.org/docs/fs_picayune_jan_2008.pdf. 